\title{
2 Spatial and temporal facies evolution of a Lower Jurassic carbonate 3 platform, NW Tethyan margin (Mallorca, Spain)
}

\author{
4 Ana Sevillano ${ }^{1}\left[\right.$ [ $\cdot$ Idoia Rosales ${ }^{2} \cdot$ Beatriz Bádenas $^{3} \cdot$ Antonio Barnolas $^{2} \cdot$ José María López-García $^{1}$
}

\section{Abstract}

Received: 17 July 2018 / Accepted: 3 December 2018

(c) Springer-Verlag GmbH Germany, part of Springer Nature 2018

\begin{abstract}
The variety of depositional facies of a Lower Jurassic carbonate platform has been investigated on the island of Mallorca along a transect comprising six stratigraphic profiles. Twenty-nine facies and sub-facies have been recognized, grouped into seven facies associations, ranging in depositional environment from supratidal/terrestrial and peritidal to outer platform. Spatial and temporal (2D) facies distribution along the transect reflects the evolution of the carbonate platform with time showing different facies associations, from a broad peritidal platform (stage 1) to a muddy open platform (stage 2), and finally to a peritidal to outer carbonate platform (stage 3). Stage 1 (early Sinemurian to earliest late Sinemurian) corresponds to a nearly-flat peritidal-shallow subtidal epicontinental platform with facies belts that shifted far and fast over the whole study area. The evolution from stage 1 to stage 2 (late Sinemurian) represents a rapid flooding of the epicontinental shallow platform, with more open-marine conditions, and the onset of differential subsidence. During stage 3 (latest Sinemurian), peritidal and shallow-platform environments preferentially developed to the northeast (Llevant Mountains domain) with a rapid transition to middle-outer platform environments toward the northwest (Tramuntana Range domain). Stages 1 and 3 present facies associations typical of Bahamian-type carbonates, whereas stage 2 represents the demise of the Bahamian-type carbonate factory and proliferation of muddy substrates with suspension-feeders. The described platform evolution responded to the interplay between the initial extensional tectonic phases related to Early Jurassic Tethyan rifting, contemporaneous environmental perturbations, and progressive platform flooding related to the Late Triassic-Early Jurassic worldwide marine transgression and associated accommodation changes.
\end{abstract}

\section{Keywords Peritidal facies $\cdot$ Carbonate platform $\cdot$ Lias $\cdot$ Mallorca $\cdot$ Balearic basin $\cdot$ Tethyan rift}

\section{Introduction}

Although ancient epicontinental carbonate platforms host the most prolific hydrocarbon reservoirs in the world, the knowledge and interpretation of their facies models have still some limitations because Holocene carbonate systems are not precise analogues for such large ancient carbonate depositional environments (Schlager 2005). These epicontinental (i.e., epeiric) carbonate platforms developed during

Ana Sevillano

a.sevillano@igme.es

1 Instituto Geológico y Minero de España (IGME), 07006 Palma de Mallorca, Spain

2 Instituto Geológico y Minero de España (IGME), Ríos Rosas 23, 28003 Madrid, Spain

3 Departamento de Ciencias de la Tierra, Universidad de Zaragoza, 50009 Zaragoza, Spain periods of global high sea level when large low-relief land areas were covered over hundreds to thousands of square kilometers with shallow seas. Facies architecture of these ancient carbonate settings differs from the recent epeiric platforms, which are much smaller, and from recent pericontinental platforms that are facing a deep ocean (Schlager 2005). The main difference lies in the fact that these ancient epicontinental platforms displayed a very low topographic gradient and as a consequence the facies belts shifted far and fast over large areas, making it difficult to track the position of the facies belts, and therefore, the profile of the platform (Schlager 2005). The facies architecture of the Sinemurian carbonate platform system of the island of Mallorca (Balearic Basin; Fig. 1a) is an example of such complexity.

The character and distribution of the facies within the Lower Lias successions of Mallorca (Soller Formation, Álvaro et al. 1989) are relatively poorly known. The few previous studies on these successions have focused on the 


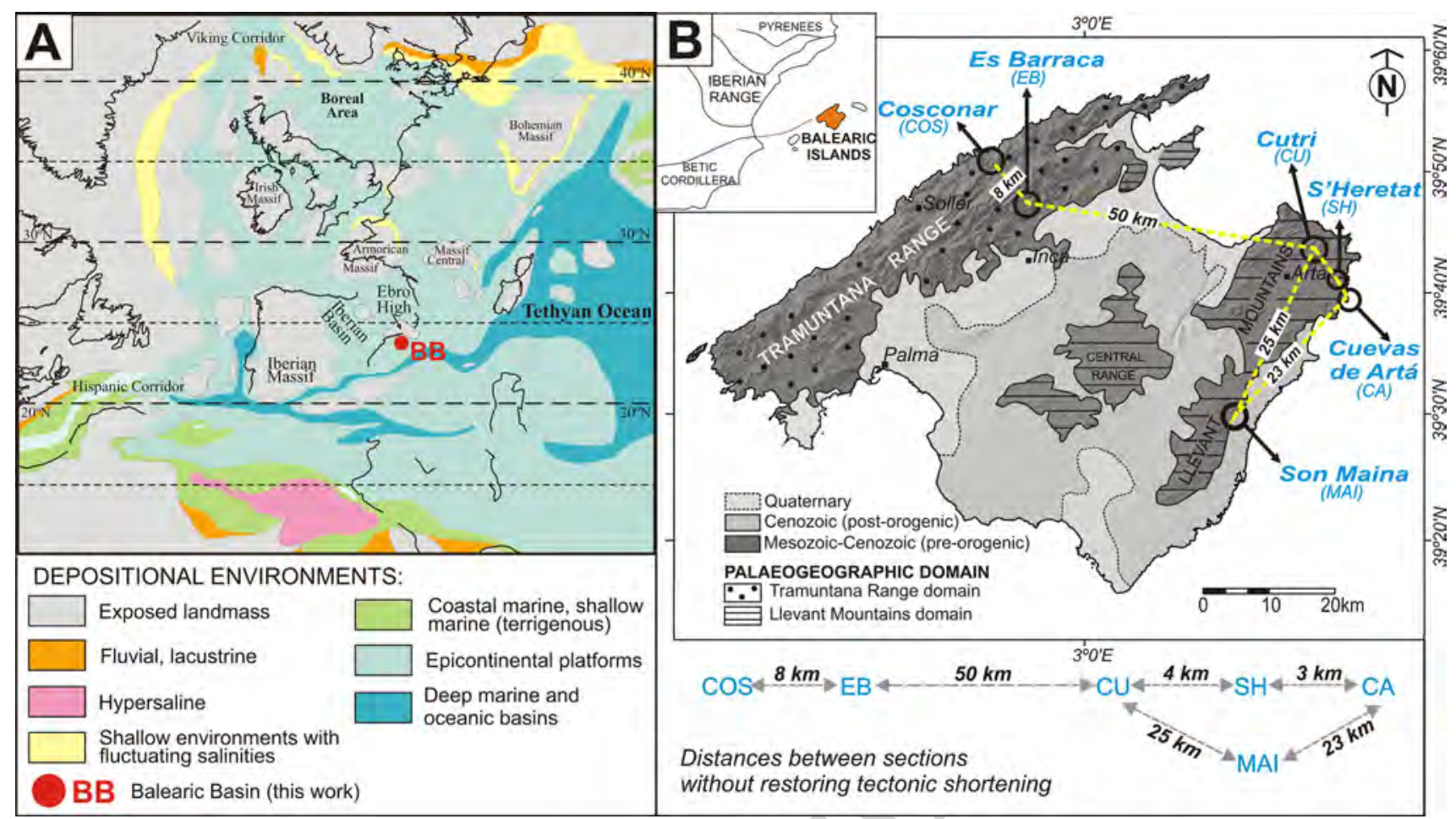

Fig. 1 Paleogeographical and geographical location of the study area. a Paleogeographical map of the western Tethys for the Sinemurianearliest Pliensbachian (modified from Dercourt et al. 2000). b Simplified geological map of the Mallorca with the location of the two main paleogeographic domains (Tramuntana Range and Llevant Moun- tains) and location of the six studied stratigraphic sections. The distances between stratigraphic sections (COS Es Cosconar, EB Es Barraca, $C U$ Cutri, $S H$ S'Heretat, $C A$ Cuevas de Artá, MAI Son Maina) are shown as today, without restoring tectonic shortening

with other contemporaneous platform successions from the Tethyan realm is also addressed.

\section{Geological setting and stratigraphic background}

The Balearic archipelago, situated in the western Mediterranean Sea, constitutes the northeast extension of the RifeanBetic alpine orogenic arc (Azañón et al. 2002). Mallorca, the biggest island of this archipelago, is formed by folded and thrusted Mesozoic-Lower Cenozoic rocks arranged into three NE-SW-oriented mountain belts: the Tramuntana Range, Central Range and Llevant Mountains (Fig. 1b; Sabat 1986; Ramos-Guerrero et al. 1989; Gelabert 1997). These mountain belts are partially surrounded by lowland plains of post-orogenic younger Cenozoic and Quaternary unconformable sedimentary rocks. The Lower Jurassic rocks studied here crop out in the Tramuntana Range and Llevant Mountains (Fig. 1b), where the main Jurassic exposures are located.

The Jurassic sedimentary successions of Mallorca represent deposition in the so-called Balearic Basin, located in the southeastern margin of the Iberian Plate, and according to

\begin{tabular}{|l|l|l|l|l|}
\hline Journal : Large 10347 & Article No : 545 & Pages : 34 & MS Code : FACI-D-18-00047 & Dispatch : 13-12-2018 \\
\hline
\end{tabular}


recent paleogeographic reconstructions, in a position adjacent to the emergent Ebro High (Fig. 1a) (Thierry 2000; Scotese and Schettino 2017). The sedimentary evolution of the basin during the Jurassic responded to the opening of the Central Atlantic Ocean and the westward progression of the Tethyan rift (Dewey et al. 1973; Dercourt et al. 2000). In particular, during the Early Jurassic the basin evolved over time from a broad shallow epicontinental carbonate platform during the Hettangian-Sinemurian, to a fragmented platform during the Pliensbachian with heterogeneous syn-rift deposition of deltaic siliciclastics, intra-shelf marls and platform carbonates. In the Toarcian-Aalenian sedimentation became hemipelagic, then followed by pelagic to slope sedimentation with residual platforms during the rest of the Jurassic (Álvaro et al. 1989).

Previous work carried out in the Jurassic of the Balearic Basin provided the regional framework and general stratigraphy of the Lower Jurassic succession of Mallorca (Álvaro et al. 1989). According to these authors, this succession starts with widespread coastal sabkha to restricted platform dolomites of the Mal Pas Formation attributed to the Hettangian, followed by the Sinemurian-lower Pliensbachian Soller Formation. The transition between the Mal Pas and Soller formations is not well established, due to the lack of fossils with biostratigraphical significance in this part of the succession, and to the pervasive diagenetic dolomitization processes affecting this transition, which hinder its recognition. The Soller Formation comprises three members (Fig. 2): shallow platform limestone of the Es Barraca Member
(Sinemurian); marl and marly limestone with brachiopods $\mathbf{A Q 2}{ }_{5}$ and scarce ammonites of the Sa Moleta Member (lowermost 126 Pliensbachian or lower Carixian), which represent deposition $\quad 127$ in an intra-shelf basin, and finally terrigenous-clastic deltaic ${ }_{128}$ deposits of the Es Racó Member (lower Pliensbachian or 129 upper Carixian). The available biostratigraphic data of this 130 succession are scarce. According to Alvaro et al. (1989) a 131 Sinemurian-earliest Pliensbachian age could be attributed 132 for the shallow-marine carbonates of the Es Barraca Mb, 133 based on their stratigraphical position and micropaleontolog- 134 ical data from benthic foraminifera and algae (Colom 1966,AQ3 5 1970, 1980; Colom and Dufaure 1962). The overlying Sa 136 Moleta Mb is attributed to the Jamesoni and Ibex ammonite 137 zones of the early Pliensbachian, based on brachiopods and 138 scarce ammonites (Uptonia jamesoni, Polymorphites sp. and 139 Tropidoceras sp.; Colom 1942; Alvaro et al. 1989).

The upper Pliensbachian (Domerian) sedimentary record (Es Cosconar Formation; Fig. 2) is more heterogeneous. Whereas some stratigraphic sections include relatively thick open-platform limestone successions, others show reduced to condensed successions of bioclastic-crinoidal limestones with quartzite pebbles. The chemostratigraphy and Sr-isotope dating of this succession have been investigated recently (Rosales et al. 2018). The Pliensbachian successions are usually overlain by a complex ferruginous hardground that represents a platform drowning unconformity (Barnolas and Simo 1984; Prescott 1988; Álvaro et al. 1989; Sevillano et al. 2010). The hardground includes a condensed ammonite fauna of early and middle Toarcian age in some of the
140

141

142

143

144

145

146

147

148

149

150

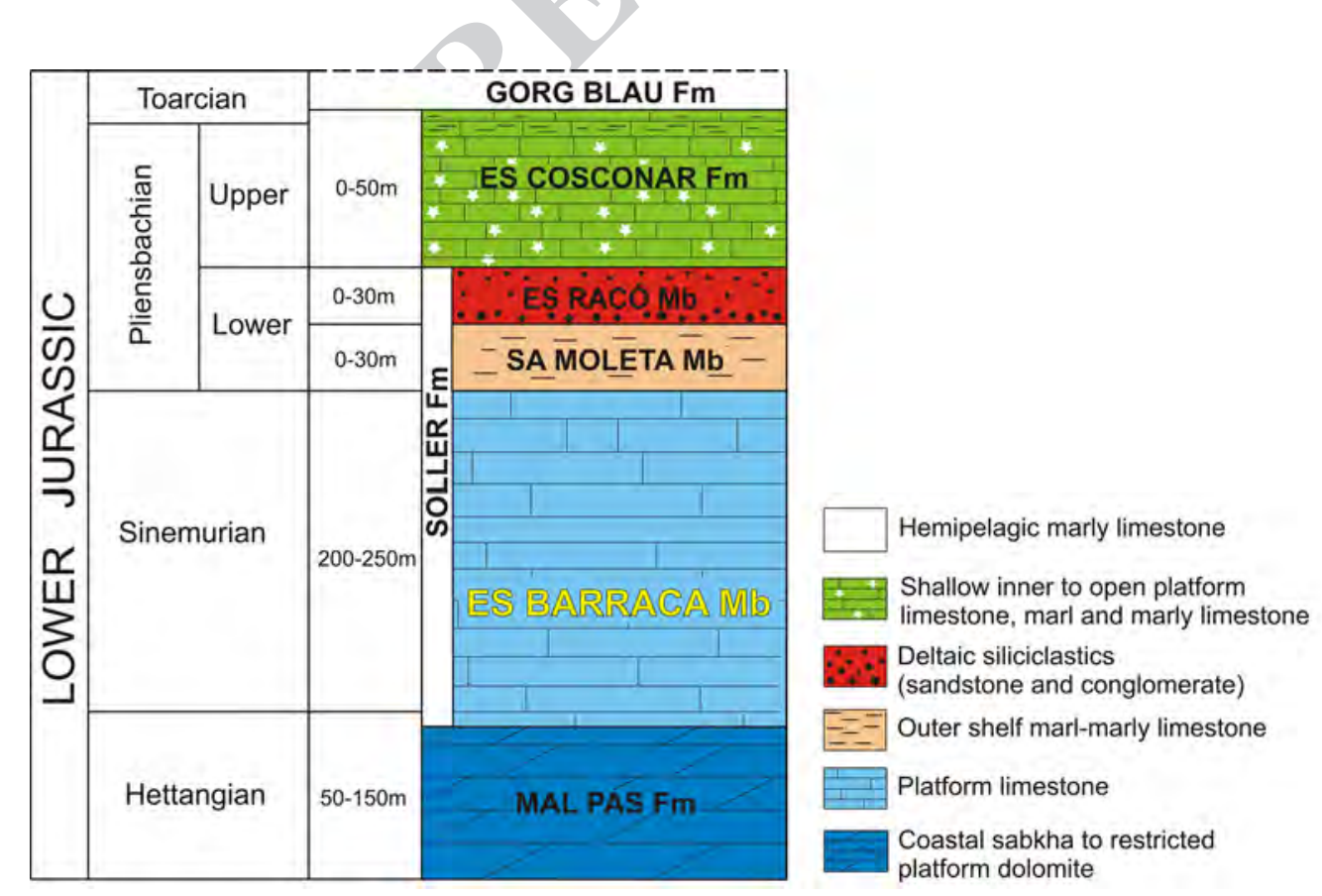

Fig. 2 General chronostratigraphic chart indicating the lithostratigraphic units of the Lower Jurassic of Mallorca Modified from Álvaro et al. (1989)

\begin{tabular}{|l|l|l|l|l|}
\hline Journal : Large 10347 & Article No : 545 & Pages : 34 & MS Code : FACI-D-18-00047 & Dispatch : 13-12-2018 \\
\hline
\end{tabular}




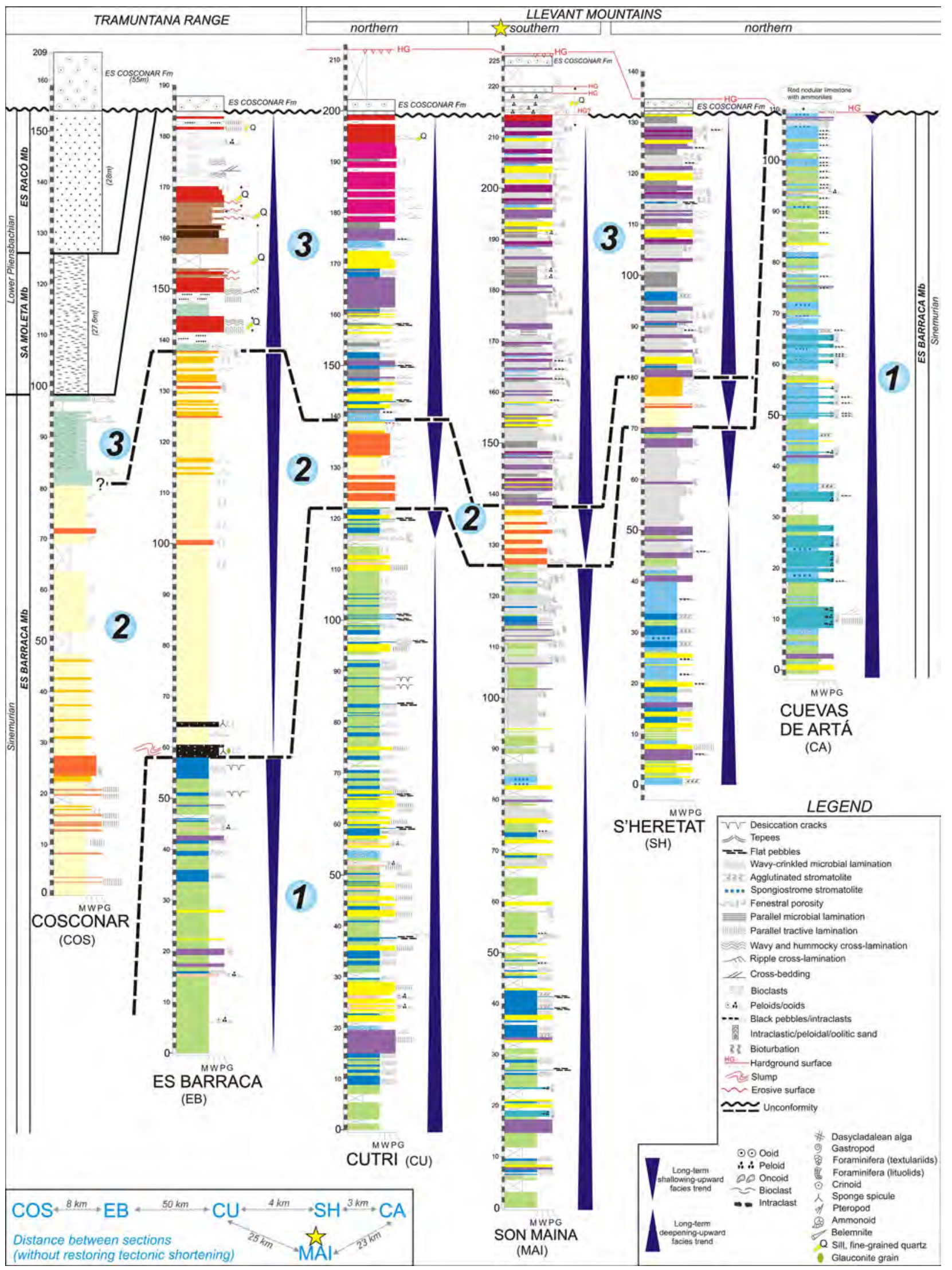


4Fig. 3 Detailed logs of the six studied stratigraphic sections. Sedimentary facies, sedimentary structures, main components, and principal fossil content are shown. The datum for stratigraphic correlation is located in the contact with the overlying Es Cosconar Fm (upper Pliensbachian). Note that the Son Maina section (yellow start) is displaced several $\mathrm{km}$ to the south with respect to the cross section defined by the other sections. Different colors represent the facies types distinguished and correspond with the facies color codes on Fig. 4. For description of facies types, the reader is referred to Table 1. Numbers 1,2, and 3 indicate the three stages of evolution of the platform system. Dark blue triangles show the general facies trends (shallowing-upward and deepening-upward) observed along the studied profiles

Tramuntana Range outcrops, and of middle Toarcian to early Aalenian in the Llevant Mountains (Álvaro et al. 1989). The Toarcian and Aalenian deposits overlying the hardground are represented by hemipelagic limestone-marl alternations of the Gorg Blau Formation.

\section{Materials and methods}

The Sinemurian shallow-water platform carbonates of the Es Barraca Member have been logged bed by bed in six stratigraphic sections (Cosconar, Es Barraca, Cutri, S'Heretat, Son Maina and Cuevas de Artá; Fig. 3), which are located along a ca. 70-km-wide transect, from the Tramuntana Range to the Llevant Mountains with no palimpastic restoration (Fig. 1b). According to Gelabert (1997) the total shortening for Mallorca, parallel to transport direction, is $48 \%$. In addition, observations of intra-shelf basinal deposits of the $\mathrm{Sa}$ Moleta Mb and siliciclastic deposits of the Es Racó Mb have also been performed in one of the sections (Cosconar), despite these members are not the aim of this study. This is because the upper datum for correlation between sections has been placed at the base of the Es Cosconar Formation (Fig. 3). Determination of facies and facies associations has been based on field observations of lithology, texture, components and sedimentary and diagenetic structures. These observations were complemented with microscope analysis of more than 230 rock samples in thin-sections, in order to identify microfacies and micropaleontological content. Description of most of the limestone textures follows the extended classification of Dunham (1962). The correlation of the stratigraphic profiles is based mainly on the vertical and lateral facies distribution, the identification of diagnostic surfaces (i.e., exposure surfaces, deepening surfaces, hardgrounds and sudden shifts in sedimentation) and the recognition of some key taxa.

The Cosconar and Es Barraca sections are located in the Tramuntana Range and are $8 \mathrm{~km}$ apart (Fig. 1b). The Cosconar section is placed at the foot of the Puig Roig peak (coordinates: $39^{\circ} 50^{\prime} 47^{\prime \prime} \mathrm{N}, 2^{\circ} 50^{\prime} 9^{\prime \prime} \mathrm{E}$; Fig. 1b). The logged profile includes $98 \mathrm{~m}$ of limestone of the upper part of the Es Barraca Member.
$27.6 \mathrm{~m}$ of marl and marly limestone with brachiopods of the Sa Moleta Member (lower Carixian) and $28 \mathrm{~m}$ of the Es Racó Member (upper Carixian). These last two members are not the object of this study. The lower part of the section is not accessible and therefore not logged. The datum of the top of the section has been located in the contact of the deltaic siliciclastics of the Es Racó Member with crinoidal limestone of the overlying Es Cosconar Formation. The Es Barraca section is located along the Inca-Lluc road (Ma-2130) (coordinates: $39^{\circ} 47^{\prime} 26^{\prime \prime} \mathrm{N}, 2^{\circ} 53^{\prime} 40^{\prime \prime} \mathrm{E}$; Fig. 1b). It is the type-section of the Es Barraca Member (Álvaro et al. 1989) and is composed of $212 \mathrm{~m}$ of well-bedded limestone overlying dolomitic breccia attributed to the Mal Pas Formation (Hettangian). Here, the lower Pliensbachian marl of the Sa Moleta $\mathrm{Mb}$ and sandstone of the Es Racó Member are missing, and the datum at the top of the succession has been placed at a bioturbated surface at the contact with quartz-pebbly, crinoidal carbonates of the Es Cosconar Formation (Domerian) (Figs. 2, 3).

The Cutri, S`Heretat, Son Maina and Cuevas de Artá sections are located in the Llevant Mountains (Fig. 1b). The Cutri section is situated west of the town of Capdepera, on the mountainside of Cutri peak (coordinates: $39^{\circ} 42^{\prime} 31^{\prime \prime} \mathrm{N}$, $3^{\circ} 23^{\prime} 38^{\prime \prime} \mathrm{E}$; Fig. 1b). Here the succession includes $200 \mathrm{~m}$ of well-bedded but dolomitized carbonates (late dolomitization according to Barnolas and Simó 1984), in spite of which a detailed facies description is possible. The S'Heretat section is located south of Capdepera (coordinates: $39^{\circ} 40^{\prime} 47^{\prime \prime} \mathrm{N}$, $3^{\circ} 25^{\prime} 55^{\prime \prime} \mathrm{E}$; Fig. $1 \mathrm{~b}$ ) and is $132 \mathrm{~m}$ thick. Its lower boundary is not well exposed, whereas the top boundary is the contact with crinoidal limestone of the Es Cosconar Formation. The Son Maina section is located in the Son Amoixa mountain range, southeast of the town of Manacor (coordinates: $39^{\circ} 30^{\prime} 49^{\prime \prime} \mathrm{N}, 3^{\circ} 15^{\prime} 4^{\prime \prime} \mathrm{E}$; Fig. 1b). It crops out in the inverted flank of a NW-SE fold (Fornós et al. 1984) and corresponds to a 220-m-thick succession of tabular limestones overlying dolomite possibly of the Mal Pas Formation (Hettangian). The datum of the top of the succession has been placed in a thin ferruginous crust overlain by limestones attributed to the Cosconar Formation. Finally, the Cuevas de Artá section is located close to Cap Vermell (coordinates: $39^{\circ} 39^{\prime} 55^{\prime \prime} \mathrm{N}$, $3^{\circ} 27^{\prime} 8^{\prime \prime}$ E; Fig. 1b). Here the Es Barraca Member is $110 \mathrm{~m}$ thick. Its lower boundary is the contact with basal dolomite attributed to the Hettangian Mal Pas Formation. The top boundary is an unconformity represented by a hardground overlain by pelagic limestone with thin-shelled bivalves referred to as filaments (pelagic forms attributed to Bositra) and ammonites of Bajocian age (Álvaro et al. 1989).

\section{Facies association and paleoenvironmental interpretation}

Based on texture, sedimentary, biogenic and diagenetic features, and fossil content (macro and microfauna), 15 facies

\begin{tabular}{|l|l|l|l|l|}
\hline Journal : Large 10347 & Article No : 545 & Pages : 34 & MS Code : FACI-D-18-00047 & Dispatch : 13-12-2018 \\
\hline
\end{tabular}


types (1-15) grouped into seven facies associations have been recognized (Figs. 3 and 4). Some facies types have been subdivided in sub-facies based on particular sedimentary features and/or components. Facies codes, facies description, and environmental interpretations are summarized in Table 1. Microfacies types and microfossil content have been illustrated in Figs. 5, 6, 7, 8, and 9, whereas some facies field aspects are shown in Figs. 10, 11, and 12.

The facies associations characterize a variety of depositional environments ranging from carbonate tidal flat to inner, middle, and outer carbonate platform (Fig. 4). However, it should be noted that the facies associations evolved with time reflecting distinct stages of carbonate platform evolution (Fig. 4).

\section{Tidal-flat facies association}

Description. The tidal-flat facies association includes facies types 1-3 (Table 1, Fig. 5). According to the prevalent subfacies, two different types of tidal-flat facies associations have been distinguished: a type 1 including facies $1 \mathrm{~A}-1 \mathrm{D}$, and a type 2 represented by facies $2 \mathrm{~A}-2 \mathrm{D}$ and 3 .

The type 1 tidal-flat facies association includes flat-pebble breccia and conglomerate with flat pieces of lithified laminated microbialite and rarely with ferruginous clasts and low-angle cross-bedding (facies 1A; Figs. 5a-b and 10a-b). It is characterized also by the presence of well-developed wavy-crinkled and parallel microbial laminites (facies 1B and $1 \mathrm{C}$ respectively; Figs. 5d-e and 10c-g), and fine-grained agglutinated stromatolites (Riding 1991; Suárez-González et al. 2014) (facies 1D). Both wavy and parallel microbial laminites show millimeter to sub-millimeter-thick micritic and microbial laminae. Tepee structures and desiccation cracks are present in facies 1B and laminoid fenestral fabric is common in facies 1C. Facies 1D is composed of alternating millimetric couplets of dense micrite and fine peloidal laminae (Fig. 5c).

The type 2 tidal-flat facies association includes blackpebble conglomerate (facies $2 \mathrm{~A}$ ) with associated shrinkage cracks, pedogenetic and stalactitic cements, spongiostrome stromatolites (facies 2B), coarse-grained agglutinated stromatolites (facies 2C), fenestral mudstones (facies 2D) and intraclastic-peloidal and oolitic-peloidal grainstones (facies 3). Spongiostrome stromatolites (facies 2B; Fig. 5f) consist of irregular anastomosing microbial laminae with irregular fenestrae and birdeyes, and common geopetal fills. By contrast, coarse-grained agglutinated stromatolites (Riding 1991; Suárez-González et al. 2014) (facies 2C; Fig. 5g) are made of alternating couplets of dense-laminated micrite and medium- to fine-grained peloidal-fenestral laminae. Fenestral mudstone (facies 2D; Fig. 5h) is formed by dense micrite with irregular fenestral pores and local fine rhizotubules and desiccation cracks. Intraclastic-peloidal and oolitic-peloidal grainstone (facies 3; Fig. 5i) consists of decimeter-thick beds with normal grading and planar to low-angle cross-lamination. The main constituents are lithic peloids, ooids, and intraclasts made of lime mudstone, dolomitic mudstone and stromatolite. Vadose features are common, including micritic and fibrous stalactitic and meniscus cements, calcrete crusts, fenestrae, root-casts, rhizoliths, early dissolution vugs and oomolds, and internal sediment (vadose silt).

Fossils are absent in the type 1 tidal-flat facies association (Table 1), whereas they are scarce and dominated by a restricted shallow-marine fauna in the type 2 tidal-flat facies association (ostracods, bivalves, gastropods, and rare fragments of dasycladalean algae and benthic foraminifera).

Paleoenvironmental interpretation In the type 1 tidal-flat the presence of laminated microbial facies such as microbial laminites (facies 1C) and fine-grained agglutinated stromatolites (facies 1D) indicate deposition in a low-energy upper intertidal zone (Aitken 1967). The presence of laminoid fenestral fabric in facies $1 \mathrm{C}$ is also typical of upper intertidal and supratidal areas with a subaerial exposure index higher than 60\% (Shinn 1983; Tucker and Wright 1990). The associated wavy-crinkle laminites (facies 1B) with tepee structures and desiccation cracks, and the flat-pebble breccia (facies 1A), reflect longer periods of subaerial exposure and deposition in a supratidal domain (Fig. 4) (Riding 1991). All these features indicate deposition on a low-energy tidal flat with a high subaerial exposure index. Occasional higher energy conditions, possibly related to storms or spring tides, may have reworked previously semi-consolidated microbial mudstone to form flat-pebble breccia and conglomerate (facies 1A). In other cases, the presence of conglomerate with low-angle cross-bedding is interpreted as the fill of shallow tidal channels in the intertidal zone.

In the type 2 tidal-flat facies association, the presence of abundant black pebbles with pedogenic features (facies 2A) is indicative of subaerial exposure with the development of calcareous and organic-rich coastal paleosoils (e.g., Miller et al. 2013), suggesting the existence of vegetated coastal areas. The black pebbles may have been derived from erosion and reworking of these calcareous coastal paleosoils (Strasser et al. 1995). In this type of tidal flat, the irregular anastomosing microbial laminated facies (facies 2B) and the agglutinated stromatolites (facies 2C) are interpreted to have been deposited in intertidal areas with intermittent exposure and desiccation (Riding 1991). The fenestral mudstone (facies 2D) represents deposition in restricted marginal ponds developed in the intertidal belt, probably under brackish-water conditions, as indicated by the scarce fauna almost limited to gastropods and small foraminifera (e.g., Harris 1986). All these characteristics suggest deposition in coastal wetlands with vegetated marsh areas (e.g., Wright and Azerêzo 2006), and facies representative of terrestrial, 


\section{STAGE-3 PERITIDAL TO OUTER CARBONATE PLATFORM latest Sinemurian}
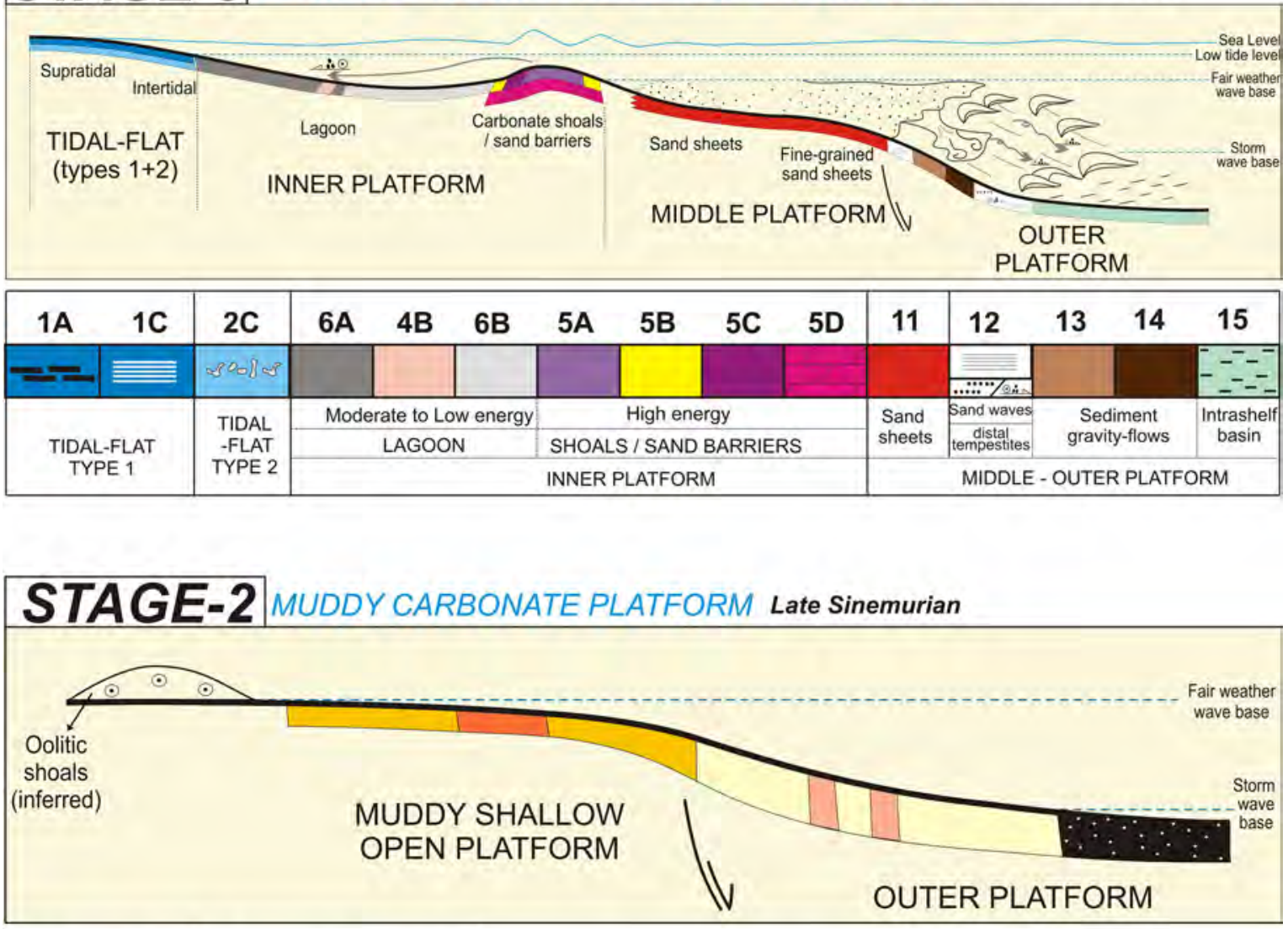

\begin{tabular}{|c|c|c|cc|}
\hline 7 A & $7 B$ & 8 & 9 & 10 \\
\hline & & & & $\ddots$ \\
\hline $\begin{array}{l}\text { MUDDY SHALLOW } \\
\text { OPEN PLATFORM }\end{array}$ & \multicolumn{3}{|c|}{ MUDDY OUTER PLATFORM } \\
\hline
\end{tabular}

\section{STA GE=1 PERITIDAL CARBONATE PLATFORM Early to earliest Late Sinemurian}

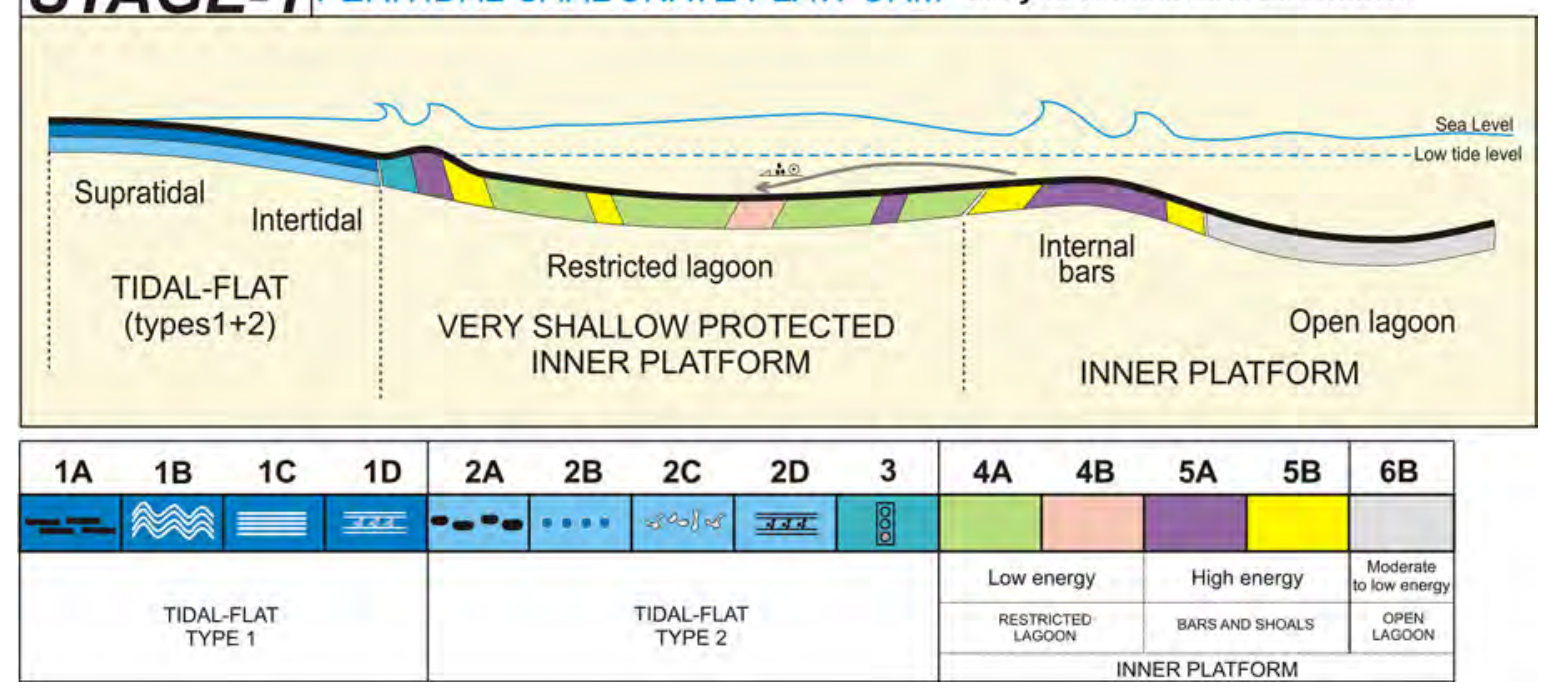

Fig. 4 Idealized platform profiles with distribution of the facies associations, facies types and depositional environments that characterize the three platform stages 1,2 and 3. Note that any geographical references are absent because these platform profiles are conceptual models

\begin{tabular}{|l|l|l|l|l|}
\hline Journal : Large 10347 & Article No : 545 & Pages : 34 & MS Code : FACI-D-18-00047 & Dispatch : 13-12-2018 \\
\hline
\end{tabular}




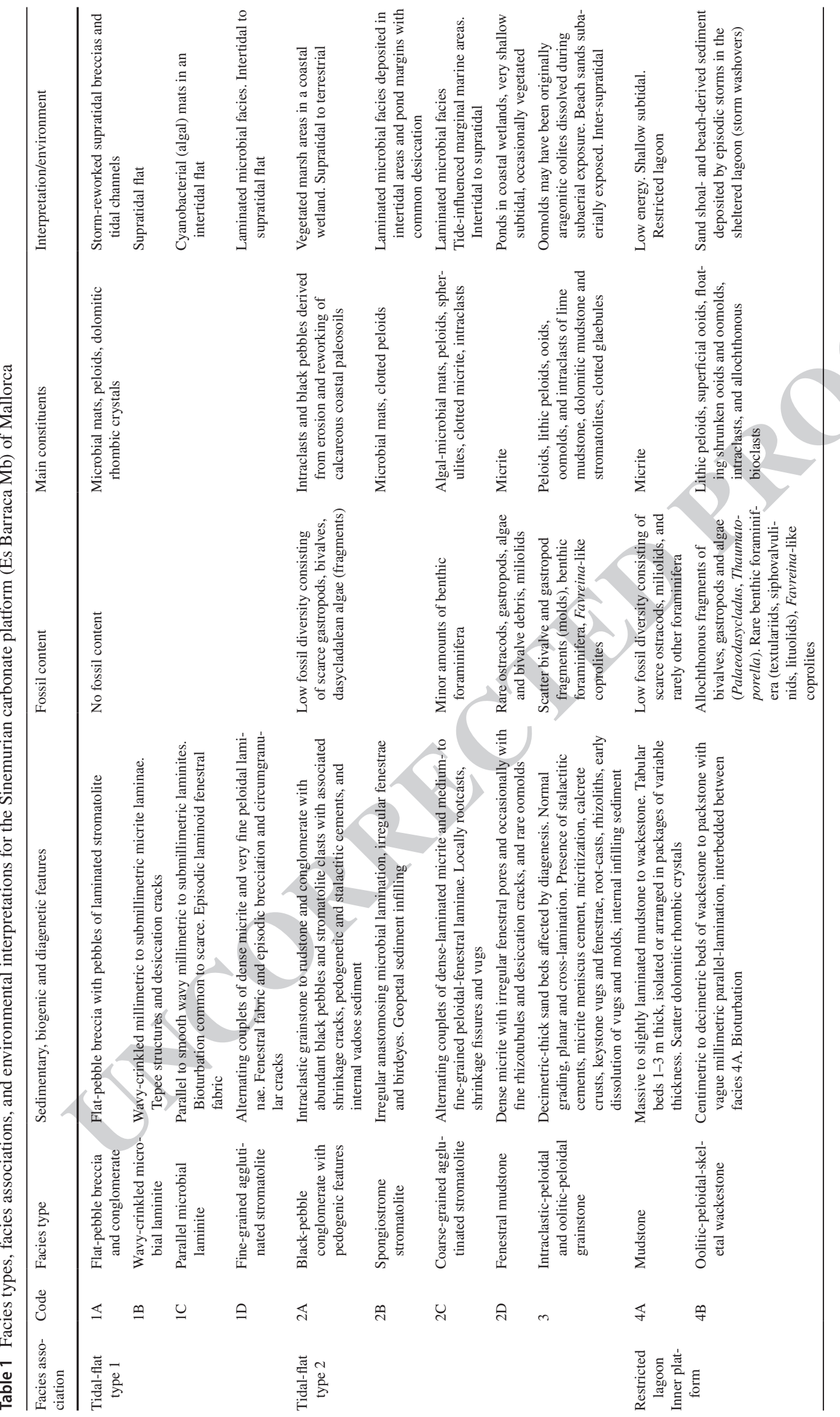




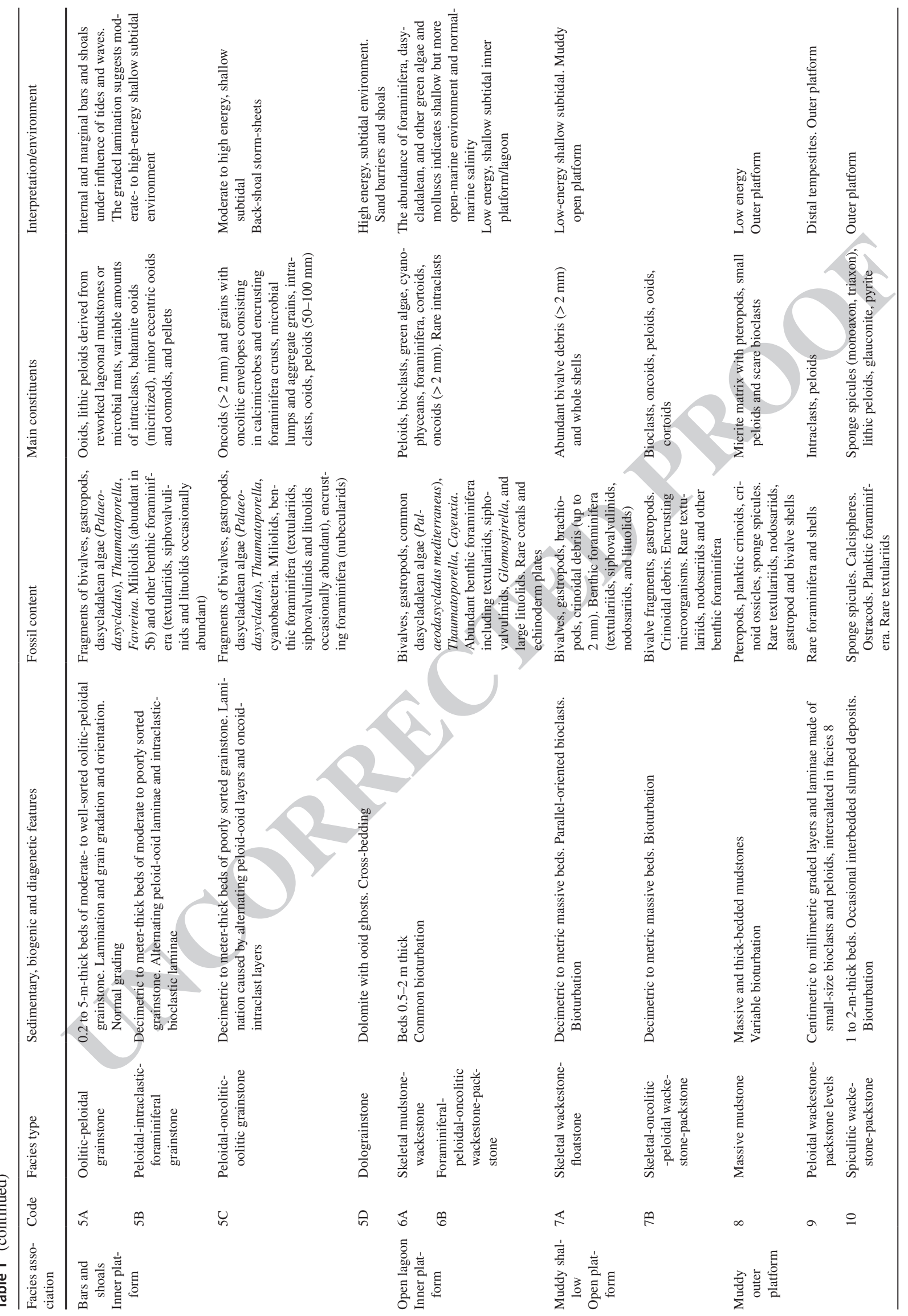




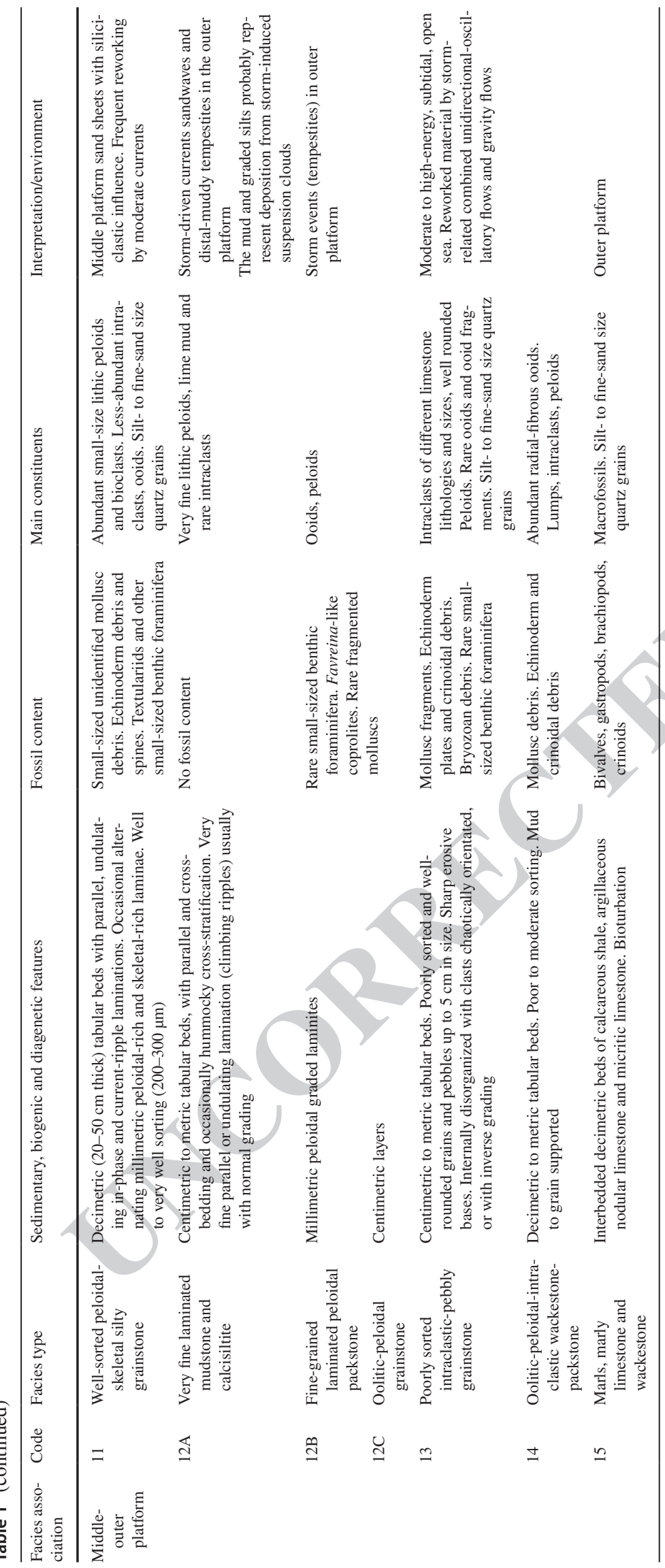

黑 Springer 
supratidal, intertidal, and pond environments. The associated planar and cross-laminated grainstone with vadose diagenetic features (facies 3 ) is interpreted as local beach sands or event beds (e.g., storms), subaerially exposed. The abundance of oomolds suggests that these ooids may have been originally aragonitic and that they were dissolved shortly after their accumulation due to subaerial exposure (Strasser 1986; Flügel 2010).

\section{Restricted lagoon facies association}

Description This facies association includes massive to slightly laminated mudstone to wackestone (facies 4A) and oolitic-peloidal-skeletal wackestone (facies 4B) (Table 1). Facies $4 \mathrm{~A}$ is arranged in 1 to 3 -m-thick tabular beds that include interlayered $\mathrm{cm}$ - to dm-thick beds of the ooliticpeloidal-skeletal wackestone of facies 4B, with faint millimetric parallel lamination and local bioturbation on top.

Mudstone to wackestone facies 4A (Fig. 6a) has a low fossil diversity consisting of scarce ostracods, miliolids and other rare small benthic foraminifera. The main constituents of facies 4B are lithic peloids, superficial ooids, floating shrunken ooids and oomolds, intraclasts, fragments of bivalves, gastropods and rare benthic foraminifera (textulariids, siphovalvulinids, and lituolids). Algae fragments including the dasycladalean Palaeodasycladus mediterraneus (Pia) and the microproblematica Thaumatoporella parvovesiculifera (Raineri) are also present (Fig. 7d-g).

Paleoenvironmental interpretation Low fossil diversity and mud-supported texture in facies 4A suggest deposition in a low-energy shallow subtidal environment, most probably in a restricted lagoon with fluctuations in seawater salinity and temperature, which inhibited the proliferation of normalmarine benthic organisms. The intermittent intercalation of grain-rich beds with tractive laminated structures (facies 4B) represents periodic interruption of the quiet-water conditions by high-energy events. They are interpreted as probable storm washover deposits, with sand bank- or shoal-derived sediments redeposited by episodic storms in the restricted lagoon, and affected by bioturbation during quiet conditions.

\section{Bars/shoals facies association}

Description This facies association is composed of four distinct grain-supported facies (Table 1): oolitic-peloidal grainstone (facies 5A), peloidal-intraclastic-foraminiferal grainstone (facies 5B), poorly sorted peloidal-oncolitic-oolitic grainstone (facies 5C) and dolograinstone (facies 5D).

The oolitic-peloidal grainstone (facies 5A; Fig. 6b) is arranged in 0.2-5-m-thick beds and are moderately to well sorted. Parallel to diffuse wavy lamination, normal grading and grain orientation are present. The peloidal-intraclasticforaminiferal grainstone (facies 5B; Fig. 6c) is arranged in $\mathrm{dm}$ - to m-thick beds. It is moderate to poorly sorted and shows alternations of peloidal-oolitic and intraclastic-bioclastic laminae. The main non-skeletal grains, in both facies $5 \mathrm{~A}$ and 5B, are ooids with micritic and/or well-developed fibrous-radial cortices (types 1 and 3 of Strasser 1986), lithic peloids derived from reworking of lagoonal mudstone and microbial laminites, along with variable amounts of intraclasts, bahamite (micritized) ooids, eccentric and shrunken (geopetal) ooids, oomolds and peloids. The heterometric peloidal-oncolitic-oolitic grainstone (facies 5C; Figs. 6d-e and $10 \mathrm{~h}$ ) is arranged in dm- to m-thick beds with lamination defined by the alternation of peloidal-oolitic layers and oncolitic-intraclastic layers. Main components of this facies are $\mathrm{mm}$ - to $\mathrm{cm}$-sized oncoids with complex cortices consisting of calcimicrobes and encrusting foraminifera crusts (type IV of Dahanayake 1977), microbial lumps and aggregate grains, intraclasts, ooids and fine-grained $(50-100 \mu \mathrm{m})$ peloids.

Fossil content in facies 5A, 5B and 5C consists of fragments of bivalves, gastropods, dasycladalean algae (Palaeodasycladus mediterraneus), microproblematic algae Thaumatoporella parvovesiculifera, favreinid coprolites (Fig. 7a, b) and benthic foraminifera including miliolids, textulariids, siphovalvulinids, and local lituolids (in facies 5C). Encrusting foraminifera (nubecularids) are locally present. Some bed tops also show bioturbation.

In the Cutri section, the previous facies exhibit strong dolomitization destroying the original texture. In this case, these facies are represented by dolograinstone (facies 5D) with ghosts of ooids and oncoids, arranged in m-thick beds with cross-bedding.

Paleoenvironmental interpretation The oolitic and peloidal grainstones (facies 5A and 5B) occur interbedded with lagoonal mudstone and laminated microbial facies of the tidal-flat facies association (Fig. 3), suggesting a shallow subtidal environment in the internal platform. The presence of ooids, intraclasts and lithic peloids, and the tractive structures (parallel to wavy lamination, normal grading, oriented bioclasts and intraclasts) suggest moderate to high energy. These facies are interpreted to represent internal and marginal sand bars and shoals (Fig. 4). The presence in some beds of shrunken ooids and oomolds could also be consistent with a shallow environment with occasional subaerial exposure of the bar tops (Mazzullo 1977), as long as such ooids are interpreted to result from meteoric dissolution of the ooid cortices (that could have been originally of evaporite minerals or aragonite) with the consequent drop of the core (Strassser 1986; Flügel 2010). Alternatively, they may be the result of the selective aggrading recrystallization of the ooid 

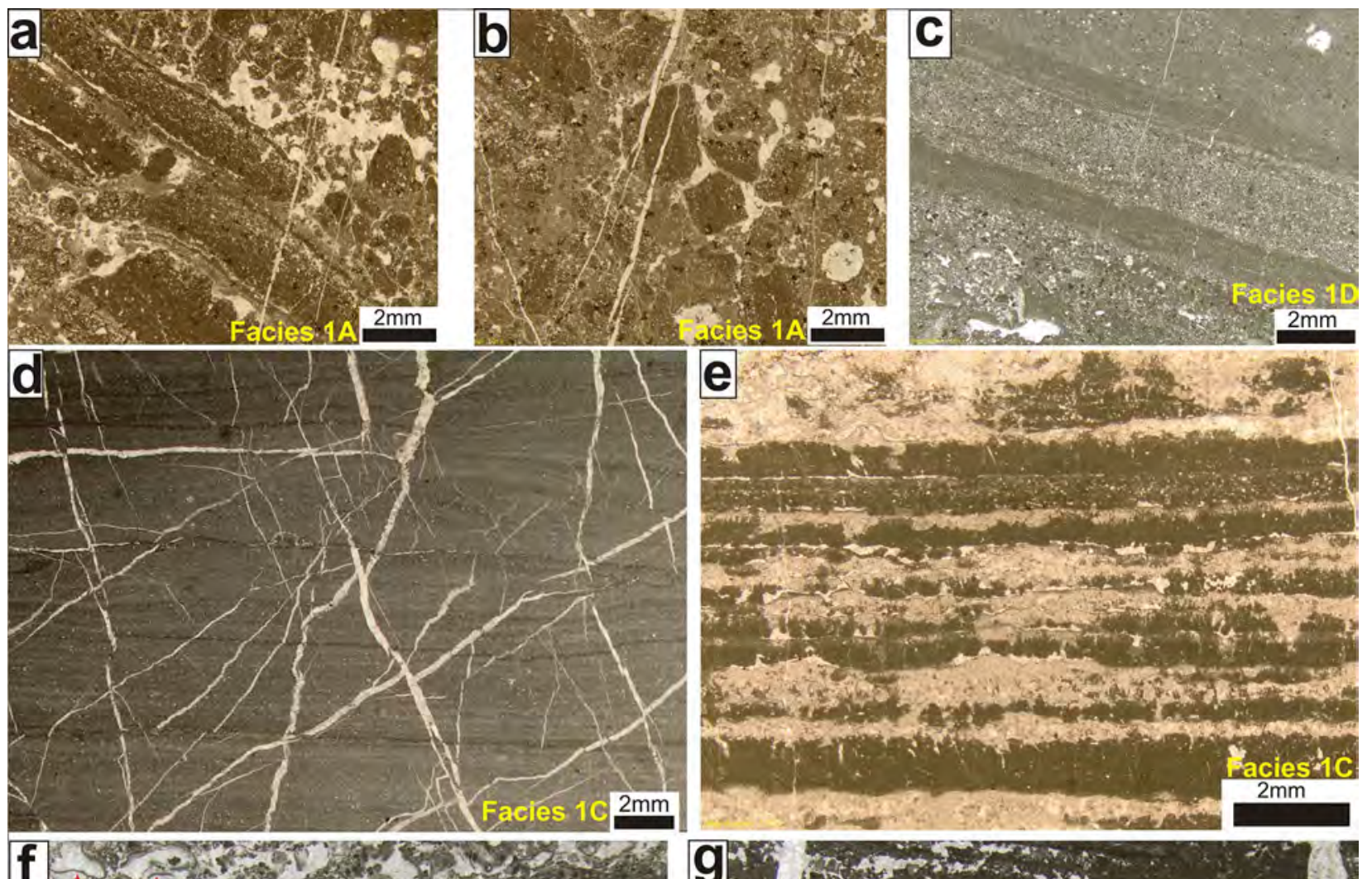

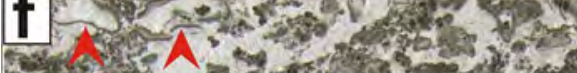
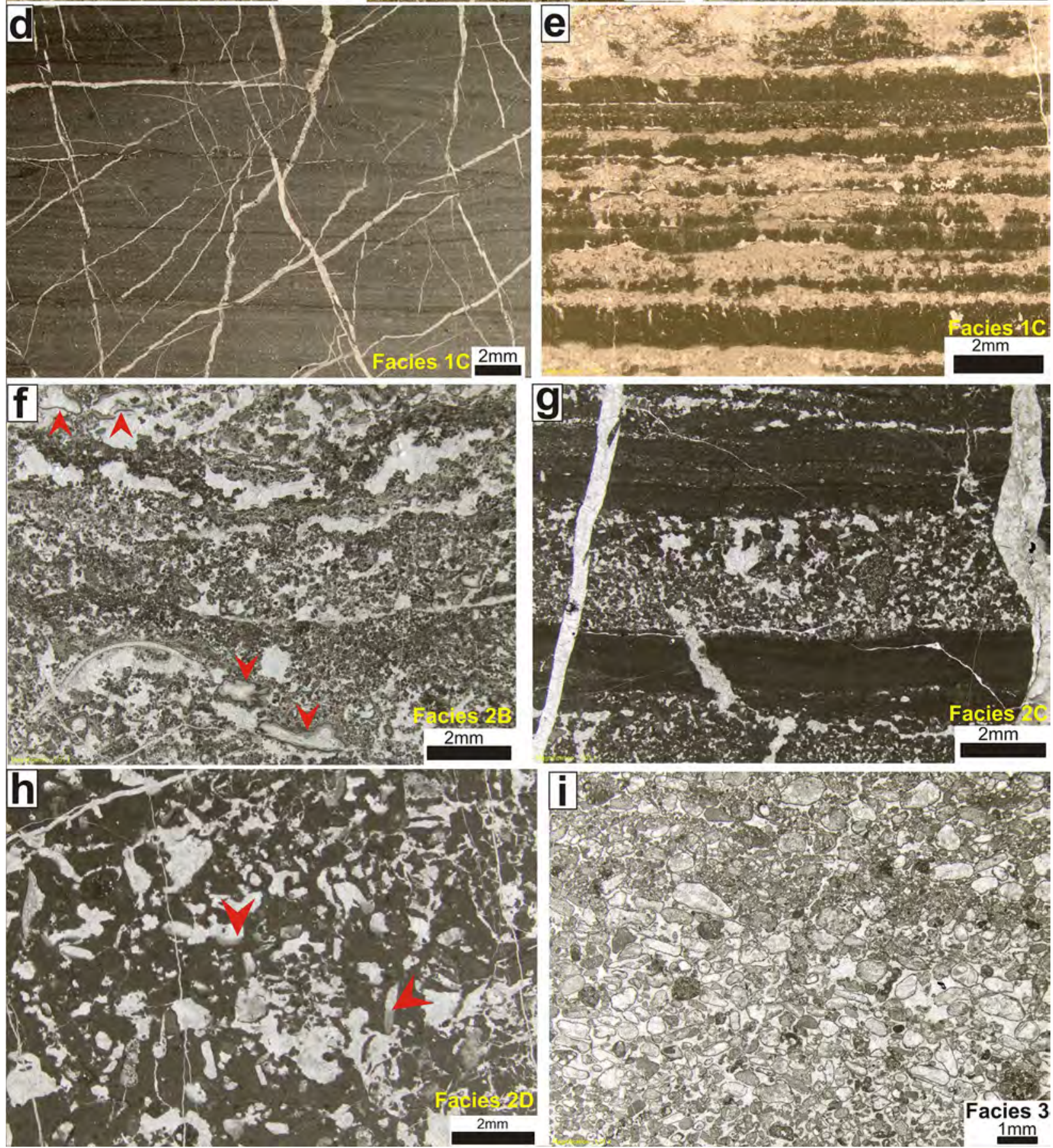
4Fig. 5 Microfacies images of the tidal-flat facies association. a, b Photomicrographs of supratidal flat-pebble breccia (facies 1A). Intraclasts are made of microbial laminite. c Fine-grained agglutinated stromatolite (facies 1D) with parallel laminae. Note the alternation of darker laminae (micritic) and lighter laminae (micropeloidal), the latter with fenestrae. d, e Parallel microbial laminites (facies 1C). Note strong dolomitization (white color) of grain-supported laminae in e. $\mathbf{f}$ Spongiostrome stromatolite (facies 2B) with irregular lamination and well-developed fenestrae. Note the presence of the microproblematic Thaumatoporella parvovesiculifera (red arrows) in the peloidalbioclastic laminae. g Coarse-grained agglutinated stromatolite (facies 2C). Note couplets of dense micrite laminae (black color) and peloidal fenestral laminae. h Mudstone with irregular fenestrae (facies 2D). Note micritic geopetal sediment filling pores (red arrows). i Intraclastic-bioclastic-peloidal grainstone (facies 3). Note micrite envelopes around grains. Some bioclasts and intraclasts dissolved and molds filled by calcite spar cement

nuclei, in response to downward-migrating meteoric waters during periods of subaerial exposure (Mazzullo 1977). The abundance in some beds of bahamite ooids points also to an original composition as aragonite for this type of grain (Vulpuis and Kiessling 2018), whereas those ooids with well-preserved concentric fibrous-radial cortices are interpreted to have been precipitated as low-magnesium calcite or as high-magnesium calcite, transformed into stable lowmagnesium calcite during very early diagenesis (Strassser 1986; Vulpuis and Kiessling 2018). The local presence of bioturbation at bed tops indicates quiet periods with stabilization of the bars.

In facies $5 \mathrm{C}$, the presence of type IV oncoids is indicative of long calm periods with intermittent agitation (Dahanayake 1977). This facies is interpreted to have been deposited in backshoal protected areas (Fig. 4). Finally, the presence of cross-bedding in dolograinstone of facies 5D is interpreted to reflect deposition in high-energy subtidal sand bars and barrier shoals.

\section{Inner platform/open-lagoon facies association}

Description This facies association consists of mud-supported and commonly bioturbated facies that includes two facies types (Table 1): skeletal mudstone-wackestone (facies 6A) and foraminiferal-peloidal-oncolitic wackestone to packstone (facies 6B). These facies are arranged in tabular, massive beds, with thicknesses ranging between 0.5 and $2 \mathrm{~m}$. The main components are bioclasts (fragments of bivalves, gastropods, Fig. 12a), algae (Palaeodasycladus mediterraneus, microproblematic Thaumatoporella parvovesiculifera, Figs. 6h, 7d-g), the calcimicrobe Cayeuxia sp. (Fig. 7c), echinoderm plates, benthic foraminifera (textulariids, siphovalvulinids, Glomospira sp. and large lituolids), peloids, cortoids and porostromate oncoids more than $2 \mathrm{~mm}$ in size (Fig. 6f-g). The oncoids have micritic, non-laminated and non-concentric thick cortices with irregular to elongate sparitic patches probably representing an irregular growth of multitaxon communities of algal filaments, Rivulariatype and other calcimicrobes, and encrusting foraminifera (Fig. 6f-g). Many of the oncoids do not have a well-differentiated nucleus (simple or complex type IV oncoids of Dahanayake 1977), but others show fragments of bivalves, gastropods, algae or intraclasts in their nuclei (type III oncoids of Dahanayake 1977).

Paleoenvironmental interpretation The abundance of foraminifera including larger lituolids, dasycladalean and other green algae, and molluscs suggests a shallow marine environment with normal-marine salinity (e.g., Barattolo and Bigozzi 1996). Mesozoic oncoids could have been formed in a wide variety of environments (e.g., Bádenas and Aurell 2010), but in this facies association, the accompanying shallow-platform components, as well as the irregular shape and the nature of oncoid cortices and nuclei suggest a shallow low-energy and protected environment (Flügel 2010). The shape of the oncoids (type III and IV) with their irregular morphology and thick cortices, and the presence of encrusting microorganisms, suggest long periods of quiet environmental conditions interrupted by occasional events of water agitation (Dahanayake 1977). Therefore, this facies association is interpreted to characterize an open lagoon or a low-energy inner platform setting (Fig. 4).

\section{Muddy shallow open-platform facies association}

Description This facies association is characterized by skeletal mudstone-wackestone to floatstone (facies 7A) and skeletal-oncolitic-peloidal wackestone-packstone (facies 7B) (Table 1, Figs. 8a-d and 12b). Both facies are arranged in massive $\mathrm{dm}$ - to $\mathrm{m}$-thick beds with common bioturbation. Facies 7A shows common skeletal fragments (typically $>2 \mathrm{~mm}$ in size; Fig. 8a) usually aligned and oriented parallel to bedding. The skeletal content includes whole shell and articulated heterodontid and megalodontid bivalves, gastropods, brachiopods, crinoids, and benthic foraminifera (textulariids, siphovalvulinids, nodosariids, and lituolids). Facies 7B contains the same bioclasts encountered in facies 7A, in addition to peloids, oncoids (types II and IV of Dahanayake 1977), cortoids (Fig. 8b-d) and locally thin ooid-rich intercalations.

Paleoenvironmental interpretation This facies association is representative of a low-energy shallow subtidal environment on a muddy platform (Fig. 4). The diversity of the skeletal content indicates open-marine conditions. The common bioturbation and the rare presence of tractive structures (oriented skeletal fragments) suggest deposition in a predominantly quiet environment below fair weather wave base. Local intercalation of ooid-rich layers suggests that the ooids

\begin{tabular}{|l|l|l|l|l|}
\hline Journal : Large 10347 & Article No : 545 & Pages : $\mathbf{3 4}$ & MS Code : FACI-D-18-00047 & Dispatch : 13-12-2018 \\
\hline
\end{tabular}




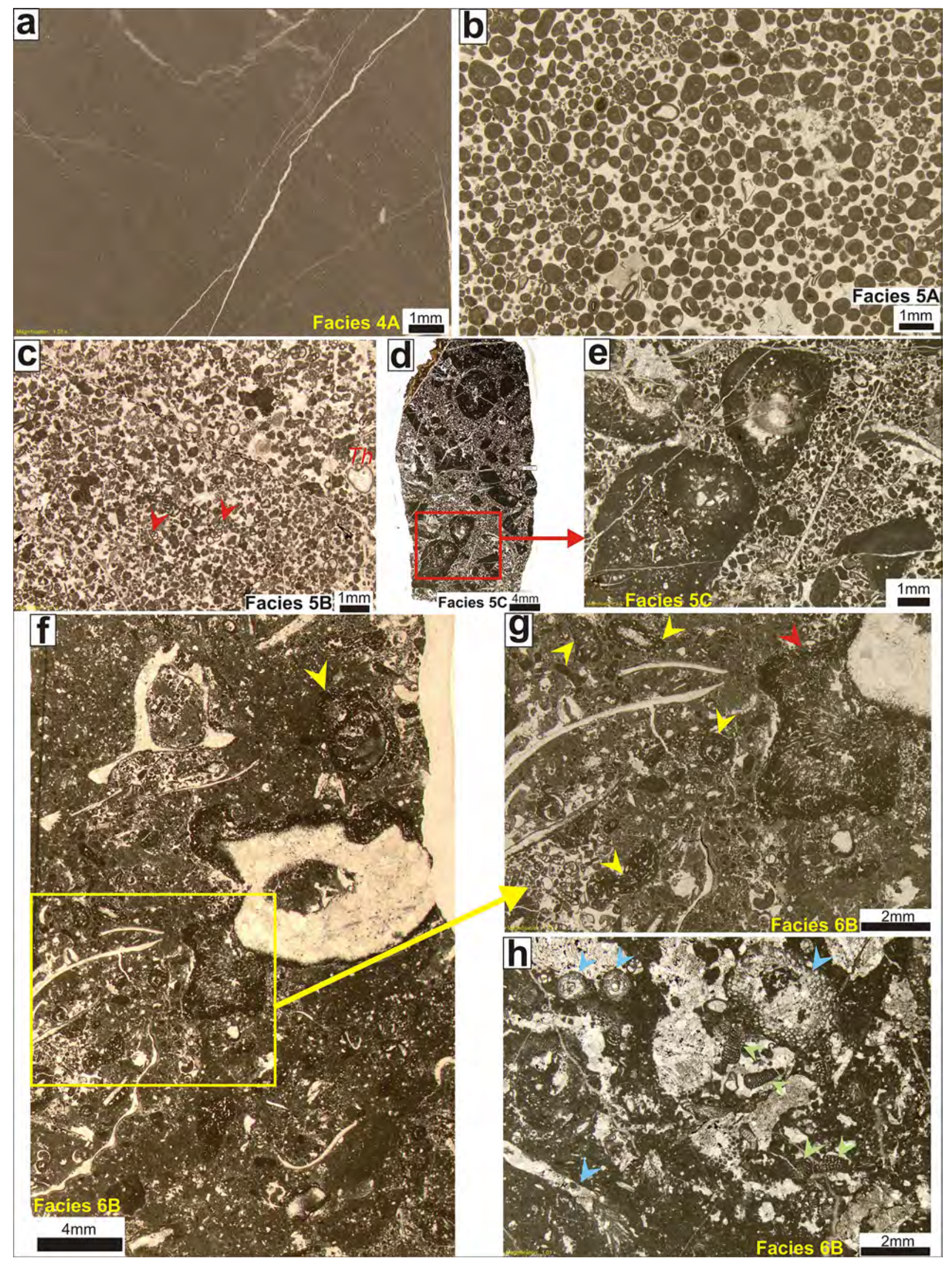


4Fig. 6 Microfacies of the restricted lagoon facies association (a), bar/ shoal facies association (b-e) and open-lagoon facies association (fh). a Pure lime mudstone of facies 4A. b Oolitic-peloidal grainstone (facies 5A). Note the widespread micritization of ooids (bahamite ooids, type 1 of Strasser 1986). c Peloidal-intraclastic-foraminiferal grainstone (facies 5B). Fragments of Thaumatoporella parvovesiculifera (Th) are present. Note the abundance of small foraminifera (some examples marked with red arrows). d, e Heterometric peloidaloncolitic-oolitic grainstone (facies 5C). Detail of simple and composite type IV oncoids (sensu Dahanayake 1977) (e). f-h Foraminiferalpeloidal-oncolitic wackestone-packstone (facies 6B). In f, g, note oncoids with simple microbial cortices (yellow arrows) and others with bioclastic nuclei and an irregular cortex composed of Rivulariatype calcimicrobes and possible encrusting foraminifers (red arrows). In $\mathbf{h}$, note abundant oblique and longitudinal sections of the alga Palaeodasycladus mediterraneus (blue arrows) and lituolids (light green arrows)

likely formed in adjacent shallower areas and were reworked

\section{Muddy outer-platform facies association}

Description This facies association includes massive mudstone (facies 8), peloidal wackestone-packstone levels (facies 9), and spiculitic wackestone-packstone (facies 10) (Table 1, Fig. 8e-i). Mudstone of facies 8 is arranged in $\mathrm{m}$-thick beds with abundant bioturbation (Fig. 12c). It contains small peloids, mm-sized planktic pteropods (Pseudocreceis liasicus Colom 1970; Fig. 8e-f), crinoid ossicles, sponge spicules, rare textulariids, nodosariids, gastropods, and bivalve shells floating in a micritic matrix. Facies 9 forms discrete $\mathrm{mm}$ - to $\mathrm{cm}$-thick graded layers intercalated in facies 8 (Fig. 8g), composed of small bioclasts, mm-sized mudstone intraclasts and peloids. The spiculitic wackestonepackstone (facies 10) is arranged in 1 to 2 -m-thick strata, with local presence of slightly slumped beds (Fig. 3, Es Barraca section). It is composed of abundant sponge spicules (monoaxon, triaxon), calcispheres, ostracods, planktic foraminifera, and rare textulariids (Fig. 8h-i). Other minor components are lithic peloids and small glauconite grains and pyrite.

Paleoenvironmental interpretation The mud-supported texture, the presence of bioturbation and the skeletal content of this facies association indicate an outer, open-marine, lowenergy environment below storm wave base, but occasionally affected by waning storm flows. During these higherenergy episodes, thin layers made of peloids and intraclasts (facies 9) were resedimented as distal tempestites (Einsele and Seilacher 1991). The presence of glauconite and pyrite may indicate slightly reducing seafloor conditions and relative low oxygen levels (Harder 1980; Fernández-Bastero et al. 2000), and the abundance of sponge spicules, calcispheres, and planktic foraminifera indicate open-marine conditions on an outer platform. The local slumped beds observed could have been triggered by episodes of oversteepening (e.g., Cook and Mullins 1983; Einsele 1991) or seismic activity (e.g., Martín-Chivelet et al. 2011).

\section{Middle to outer platform facies association}

Description This facies association consists of seven facies types (facies 11-15, Table 1), which can be either matrix or grain supported. Facies 11 consists of well to very well sorted peloidal-skeletal fine-grained grainstone (Fig. 8j-1), arranged in tabular beds $20-50 \mathrm{~cm}$ thick, with plane-parallel, undulating in-phase and current-ripple lamination. Locally, it shows alternating, millimeter-thick, peloidal-rich, and skeletal-rich laminae. The main constituents are small (100-200 $\mu \mathrm{m})$ lithic peloids and bioclasts (Fig. 81). Less abundant are intraclasts, ooids, and silt to fine-grained sand quartz grains (Fig. 8j-k). The fossil content consists of small unidentified mollusc debris, echinoderm plates and spines, textulariids, and other small benthic foraminifera.

Facies $12 \mathrm{~A}$ consists of very fine laminated mudstone and calcisiltite, arranged in cm- to m-thick tabular beds, with plane-parallel and undulated climbing-ripple lamination, hummocky cross-lamination and cross-bedding in sets up to $1 \mathrm{~m}$ thick. Calcisiltite ( $>50 \%$ of detrital silt-sized carbonate particles) is characterized by very fine mm-thick laminae, with usual normal grading (Fig. 9a). The components are lime mud and very fine to medium silt-sized lithic peloids and rare intraclasts. Facies $12 \mathrm{~B}$ is associated with facies $12 \mathrm{~A}$, but differs from it in the larger size of the particles. It consists of mm-thick laminae of graded, fine-grained peloidal packstone (Fig. 9b-c) interlayered with laminated mudstone (facies 12A). Facies 12C consists of cm-thick layers of oolitic-peloidal grainstone that are interbedded with facies 12A and 12B (Fig. 9d).

Facies 13 consists of poorly sorted intraclastic pebbly grainstone to rudstone. It occurs in $\mathrm{cm}$ - to m-thick tabular beds with sharp erosive bases and clasts and pebbles usually chaotically oriented (Figs. 9e and 12d) or with inverse grading (Fig. 11f-g). The intraclasts and pebbles are well rounded. Principal components are intraclasts of different limestone lithologies (lime mudstone, skeletal wackestone, oolitic grainstone, peloidal grainstone, etc.) and sizes (up to $5 \mathrm{~cm}$ ), rare $\mathrm{cm}$-sized and rounded quartzite extraclasts, scarce ooids and ooid fragments, and silt- to fine sand-sized quartz and carbonate grains (Fig. 9f). Fossil content includes mollusc fragments, echinoderm plates and crinoidal debris, bryozoan debris and rare small-sized benthic foraminifera. Facies 14 usually appears associated with facies 13 and consists of poorly to moderately sorted oolitic-peloidal-intraclastic wackestone to packstone, arranged in dm- to m-thick tabular beds. The main components are ooids, many with a

\begin{tabular}{|l|l|l|l|l|}
\hline Journal : Large 10347 & Article No : 545 & Pages : $\mathbf{3 4}$ & MS Code : FACI-D-18-00047 & Dispatch : 13-12-2018 \\
\hline
\end{tabular}




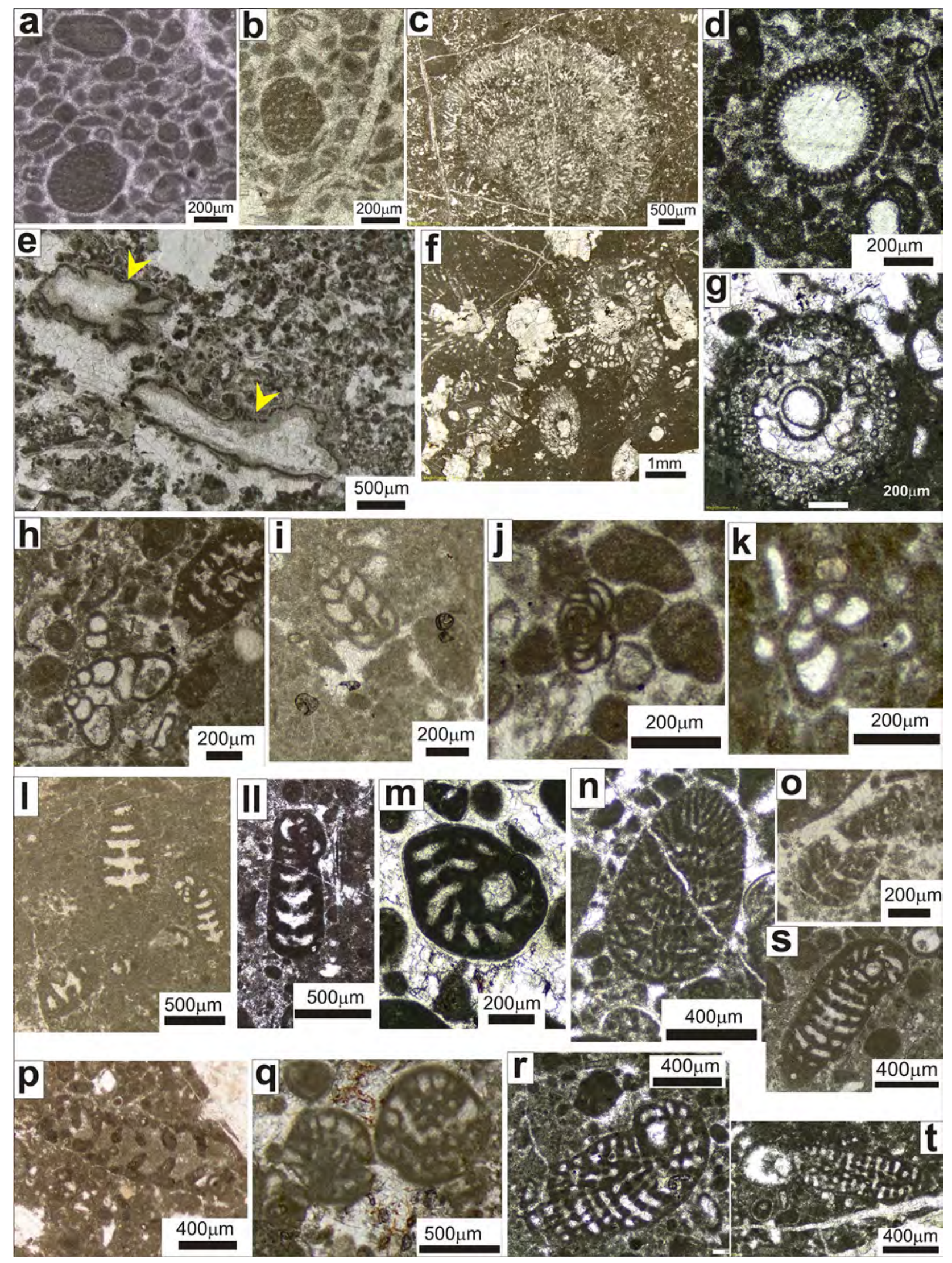


4Fig.7 Images of representative microfossils and microcoprolites from the Es Barrraca Member. a, b Favreina-like coprolites. c Cayeuxia sp. d, e Thaumatoporella parvovesiculifera. $\mathbf{f}-\mathbf{g}$ Palaeodasycladus mediterraneus. h, i Siphovalvulina sp. j Meandrovoluta asiagoensis. k Duotaxis sp. 1-ll Mesoendothyra sp. m Paleomayncina termieri. n Haurania deserta. o Amijiella amiji. p Everticyclammina praevirguliana. $\mathbf{q}-\mathbf{s}$ Lituosepta recoarensis. $\mathbf{t}$ Orbitopsella primaeva (primitive form)

radial-fibrous fabric (type 4 of Strasser 1986), lumps, intraclasts and peloids (Fig. 9g).

Facies 15 consist of alternating marl, marly limestone and wackestone arranged in dm-thick beds bearing macrofossils of bivalves, gastropods, brachiopods and crinoids (Fig. 9h).

Paleoenvironmental interpretation Facies 11 is interpreted as peloidal-skeletal sand sheets with some siliciclastic influence (silt and fine-sand quartz grains) which accumulated on a middle platform area below fair weather wave base. The associated sedimentary structures (parallel, undulating and current-ripple crosslamination; Fig. 11d-e) suggest frequent reworking by moderate currents and probably storms. Facies 12-15 formed in an outer platform environment. The occurrence in facies $12 \mathrm{~A}$ of undulating climbing lamination and cross-bedding with sets up to $1 \mathrm{~m}$ thick indicates migration of large bedforms and rapid sedimentation rates with a combination of deposition by traction and suspension, which was probably caused by storm-generated currents on the outer platform (e.g., Chaudhuri 2003; Payros et al. 2010; Brandano et al. 2012). The presence of local hummocky cross-lamination in facies $12 \mathrm{~A}$ and the intercalation of lime-mud layers in facies $12 \mathrm{~B}$ and $12 \mathrm{C}$ probably reflect storm waye action and deposition from storm-induced suspension clouds. The coarse-grained grain- and matrix-supported facies 13 and 14 are interpreted as sediment derived from the erosion of penecontemporaneous platform deposits, which probably were transported to the outer platform by combined unidirectional and oscillatory flows and/or gravity flows (Vierek 2010). The inverse grading of grains and pebbles (Fig. 11f-g) that occurs in some beds suggests avalanching or grain-to-grain collision processes (Tucker and Wright 1990; Dasgupta and Manna 2011). The nature of the clasts in grain-supported pebbly limestone, with a predominance of well-rounded intraclasts of different textures indicate reworking and transport of clasts from different areas on the platform. These flows may have been triggered by either strong storms or slope instability related to the onset of rifting (see below). The marl, marly limestone, and wackestone (facies 15) represent argillaceous-rich sedimentation on the outer platform.

\section{Facies architecture and platform stages}

The vertical and lateral arrangement of facies in the Sinemurian carbonate succession of the Mallorca (Es Barraca Member) has allowed the identification of three stages in the evolution of the platform (stages 1-3 from older to younger; Figs. 3, 4 and 13), which are characterized by distinctive microfossil assemblages, facies architecture and platform profiles.

\section{Biostratigraphic constraints of platform stages}

The recognition of benthic microfossil assemblages along the six studied stratigraphic profiles has allowed a better age constraint of the defined platform stages. Thus, the fossil assemblage of the lower part of stage 1 shows, in all sections, a relatively low diversity of benthic foraminifera taxa, that consists of Siphovalvulina sp. (Fig. 7h-i), Meandrovoluta asiagoensis Fugagnoli and Rettori (Fig. 7j), Glomospira sp., Mesoendothyra sp. (Fig. 71-11), Duotaxis sp. (Fig. 7k) and some textulariids. According to Velić (2007) this association could be compatible with an early Sinemurian age. The upper part of stage 1 shows in addition Haurania sp., Everticyclammina praevirguliana Fugagnoli, and Lituosepta recoarensis Cati. The presence of $L$. recoarensis indicates already a late Sinemurian age for the upper part of stage 1, according to its stratigraphic occurrence in the Tethyan margins (Septfontaine 1984; Boudagher-Fadel and Bosence 2007; Velić 2007; Fugagnoli and Bassi 2015). The less restricted inner platform environments during this stage are also characterized by the abundance of calcareous algae including Palaeodasycladus mediterraneus (Pia) (Fig. 7f, g), microproblematic Thaumatoporella parvovesiculifera (Raineri) (Fig. 7d-e) and the calcimicrobe Cayeuxia sp. According to these data, an early Sinemurian to earliest late Sinemurian age is attributed to platform stage 1 .

The following stage 2 shows a poorer fossil assemblage of benthic algae and foraminifera that includes few specimens of nodosariids, Siphovalvulina sp., Glomospira sp., Everticyclammina praevirguliana Fugagnoli, Amijiella amiji (Henson) (Fig. 7o) and Lituosepta recoarensis Cati, indicating a late Sinemurian age. Finally, the benthic foraminifera assemblage of stage 3 includes, in addition to Lituosepta recoarensis Cati (Fig. 7q-s), also Haurania deserta Henson (Fig. 7n), Amijiella amiji Henson, Paleomayncina termieri (Hottinger) (Fig. 7m), Everticyclammina praevirguliana Fugagnoli (Fig. 7p) and primitive forms of Orbitopsella primaeva (Henson) in the upper part (Fig. 7t). According to Septfontaine (1984) and Velić (2007), this assemblage
665

666

667

668

669

670

671

672

673

674

675

676

677

678

679

680

681

682

683

684

685

686

687

688

689

690

691

692

693

694

695

696

697

698

699

700

701

702

\begin{tabular}{|l|l|l|l|l|}
\hline Journal : Large 10347 & Article No : 545 & Pages : 34 & MS Code : FACI-D-18-00047 & Dispatch : 13-12-2018 \\
\hline
\end{tabular}



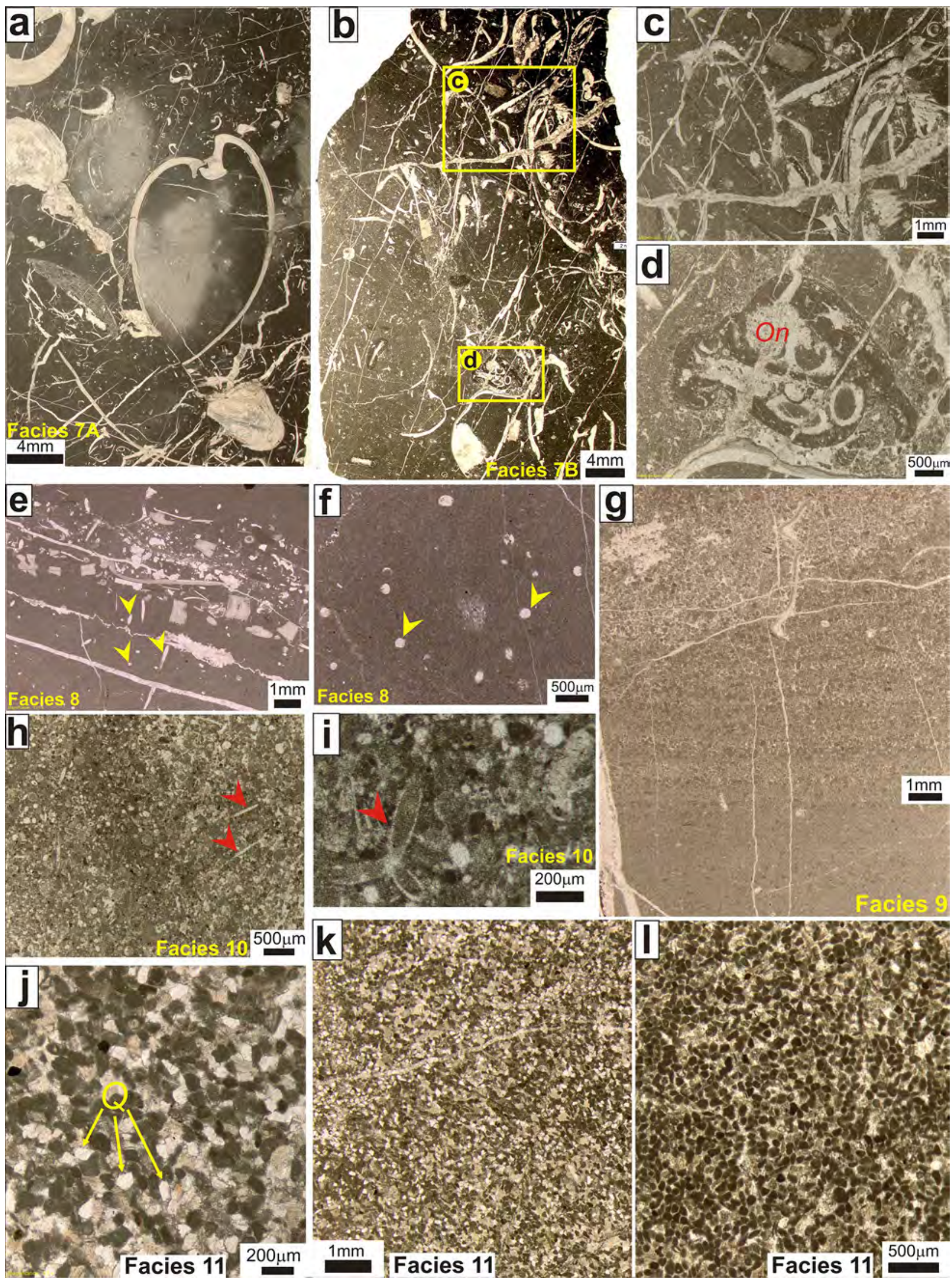
4Fig. 8 Microfacies of muddy shallow open-platform (a-d), muddy outer-platform $(\mathbf{e}-\mathbf{i})$, and middle-outer platform $(\mathbf{j}-\mathbf{l})$ facies association. Photographs made with binocular microscope. a Skeletal wackestone (facies 7A). Note the presence of whole and articulate bivalve shells. b-d Skeletal-oncolitic-peloidal wackestone to packstone (facies 7B). See details of bioclasts (bivalves, crinoids) in photo $\mathbf{c}$ and of oncoids (On) in photo d. e-f Massive mudstone. Note the presence of pelagic pteropods (yellow arrows), possibly Pseudocreceis liasicus Colom 1970. g Thin peloidal levels (facies 9) with fine parallel tractive laminae. $\mathbf{h}-\mathbf{i}$ Spiculitic packstone (facies 10). Note monoaxon and triaxon sponge spicules (red arrows). j-l Homometric peloidalskeletal fine-grained grainstone (facies 11). Note siliciclastic influence consisting of abundant very fine sand and silt-size quartz grains $(\mathbf{j}, \mathbf{k})$

suggests a late Sinemurian to latest Sinemurian age for the

upper part of stage 3 .

\section{Stage 1: peritidal carbonate platform (early-earliest late Sinemurian)}

Stage 1 represents a large, widespread peritidal carbonate platform characterized throughout the whole study area by deposition of shallow subtidal, intertidal, and supratidal facies associations, arranged in typical peritidal meter-scale shallowing-upward cycles (e.g., Strasser 1991; James 1984; Pratt et al. 1992; Bosence et al. 2000, 2009), which are not a topic of this study. This stage has been characterized in all the studied sections except in the Cosconar section (Fig. 3), where the outcrops of this part of the succession are inaccessible. The sedimentary thicknesses for this stage range from $58 \mathrm{~m}$ (Es Barraca section, Fig. 3) to $126 \mathrm{~m}$ (Son Maina section, Fig. 3). The base of platform stage 1 is represented in all the studied sections by a rapid upward change from dolomite of the Mal Pas Formation, attributed to the Hettangian and deposited in a coastal sabkha to restricted platform environments (Álvaro et al. 1989), to the Sinemurian shallow peritidal facies of the Es Barraca Member.

Stage 1 is composed mostly of an alternation of facies types 1 to 6 (Table 1), representative of tidal-flat, restricted lagoon and shallow inner-platform facies associations ( 1 in Fig. 13). The lateral facies distribution shows that most of these environments are represented in each of the studied sections from both the Tramuntana and Llevant Mountains ranges (Fig. 3), indicating far and rapid migration of facies belts as a consequence of the very low topographic gradients during this stage (Schlager 2005). In spite of this, there are some patterns in the distribution of the facies associations (Fig. 14). In particular, intertidal to supratidal facies, mainly of the type 2 tidal-flat facies association (facies 2A-2D and 3 ), are dominant to the northeast (Cuevas de Artá section, Figs. 3, 13 and 14). In this area, the intertidal facies include spongiostrome (facies 2B) to coarse-grained agglutinated stromatolites (facies 2C) and fenestral limestone (facies 2D), whereas supratidal facies include abundant levels with black-pebble conglomerate, intraclasts of stromatolite and pedogenic features (facies 2A). This suggests the prevalence of subaerial exposure phases, with erosion and reworking of microbial laminites and calcareous coastal paleosoils developed in vegetated marsh areas (e.g., Wright and Azerêdo 2006). These facies are interbedded with a slightly lower amount of subtidal mudstone (facies 4A; Fig. 14) deposited in low-energy, shallow restricted lagoons. Higher-energy shallow subtidal facies represented by oolitic-peloidal shoals and inner bars (facies 5A-5B), although present, are scarce (Fig. 14) and also show evidence of subaerial exposure (abundance of bahamite and shrunken ooids and oomolds). All these features suggest that this area represented the shallowest part of the platform during this stage 1, developed probably in a coastal wetland with frequent subaerial exposure (Leinfelder 1987; Vera and Jimenez de Cisneros 1993; Wright and Azerêdo 2006).

Toward the southwest (Son Maina section, Fig. 3) and to the west (S'Heretat section, Fig. 3) of the Cuevas de Artá section, there is a prevalence of tidal-flat facies association of the two types (type 1 and type 2), interbedded with facies from restricted lagoon (facies 4A) and higher-energy inner bars and shoals (facies 5A-5B), in the lower half of the stage 1 succession (Fig. 14). In contrast, the upper half of the stage 1 succession is widely dominated by lagoonal facies (facies 6A; Figs. 3, 14), with the abundant presence of benthic foraminifera and calcareous algae that are indicative of a more open-marine environment but still in the shallow inner platform. This vertical and lateral trend suggests a slight general increase in the topographic gradient of the depositional profile towards these areas at least for the upper half of stage 1. Mostly to the west (Cutri section, Fig. 3), although the proportion of tidal-flat facies associations in both the lower and upper halves of stage 1 remains equal, there is an increase in the proportion of facies from restricted lagoons, a relative decrease of the higher-energy inner bar/ shoal facies, and an occurrence of open-lagoon facies (about meter 100 of the section) in the upper half (Fig. 14), suggesting a similar trend of facies to that observed for the previous sections. An opposite trend is observed to the northwest in the Tramuntana Range (Es Barraca section), where there is an overall predominance of inner platform facies (restricted lagoon and inner bars/shoals facies associations) over the tidal-flat environments in the lower half, whereas towards the upper half, type 1 tidal-flat facies association becomes more abundant, decreasing the relative proportion of facies from restricted lagoon (Fig. 14).

\section{Stage 2: muddy carbonate platform (late Sinemurian)}

The contact between stage 1 and stage 2 corresponds to a deepening surface on top of the peritidal facies of stage 1 , giving way to open shallow to outer platform facies
788

\begin{tabular}{|l|l|l|l|l|}
\hline Journal : Large 10347 & Article No : 545 & Pages : $\mathbf{3 4}$ & MS Code : FACI-D-18-00047 & Dispatch : 13-12-2018 \\
\hline
\end{tabular}



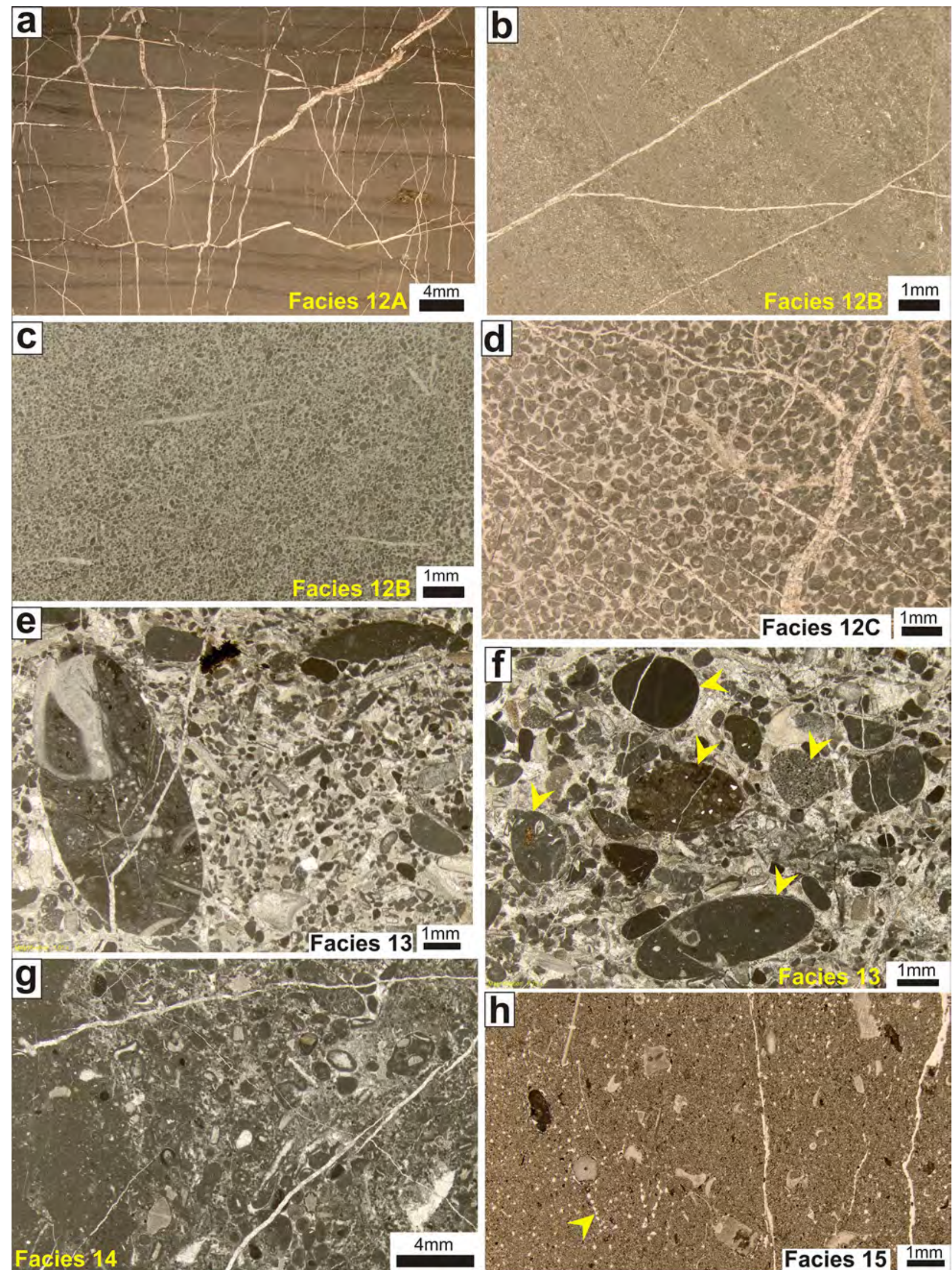
4Fig. 9 Microfacies of outer-platform facies association. a Very fine laminated mudstone and calcisiltite (facies 12A). b Very fine-grained, laminated peloidal packstone grading to mudstone (facies 12B). c Very fine peloidal grainstone with millimetric graded laminae (facies 12B). d Oolitic-peloidal grainstone (facies 12C). e-f Heterometric intraclastic-pebbly grainstone (facies 13) under binocular microscope. Note different composition of limestone pebbles (yellow arrows). g Oolitic-peloidal-intraclastic wackestone to packstone (facies 14). h Marly limestone of the outermost platform under binocular microscope. Note the abundance of fine-grained quartz silt (yellow arrow) and crinoidal fragments (facies 15)

associations deposited on a muddy carbonate platform (Figs. 4, 13). This platform is constituted by facies types 7-10 (Table 1; Fig. 8). The lateral distribution of facies shows relatively shallower environments and a thinner $(10-20 \mathrm{~m})$ sedimentary succession to the east, in the Llevant Mountains domain (Cutri, S'Heretat and Son Maina sections, Fig. 3). Facies in this area are composed mainly of skeletal wackestone (facies 7A) and skeletaloncolitic-peloidal wackestone to packstone (facies 7B), with some floatstone beds rich in megalodontid bivalves and gastropods, interbedded with minor amounts of massive mudstone (facies 8) and spiculitic packstone (facies 10) (Figs. 4, 13). Megalodont-rich floatstone and oncolitic wackestone indicate a shallow muddy substrate in a lowenergy platform interior (Flügel 2010), whereas the abundance of crinoid and brachiopod debris and nodosariids (facies 7B; Table 1) indicate a connection with the open sea. Less common is the presence within facies 7B of isolated ooid-rich layers with foraminifera, which are interpreted to be reworked from an inferred adjacent nonoutcropping (or eroded) oolitic belt developed in shallower portions of the platform. In the northeasternmost area of the Llevant Mountains (Cuevas de Artá section) stage 2 is missing (Figs. 3, 13) most probably due to post-depositional erosion during a subsequent extensional tectonic phase, or alternatively, due to non-deposition.

To the northwest, in the Tramuntana Range domain (Es Barraca and Cosconar sections, Figs. 3 and 12e), the contact with the underlying stage 1 is marked by the sudden occurrence of spiculitic wackestone-packstone (facies 10), locally slightly slumped, over tidal-flat laminites, indicating a sharp environmental change to deeper water conditions (e.g., Rychliński et al. 2018a) and some displacement of unconsolidated material. This indicates a probable increase of the depositional dip towards this domain and higher sedimentation rates (Fig. 13). Here, stage 2 shows a thicker succession $(\sim 80 \mathrm{~m})$ compared to the sections of the Llevant Mountains domain (Fig. 14), and is constituted principally by thick-bedded bioturbated mudstone (facies 8 ) with some intercalated centimetric to metric beds of skeletal-oncolitic wackestone-packstone with bivalves, gastropods, brachiopods and echinoderm debris (facies 7A, B), and layers of peloidal packstone (facies 9) (Fig. 14). The later are interpreted as reworked material, resedimented from the shallower zone located to the east, probably during storm events (tempestites). All these features suggest deposition in an outer platform environment (Fig. 13).

\section{Stage 3: Peritidal to outer carbonate platform (latest Sinemurian)}

The transition of platform stage 2 to stage 3 marks a rapid sedimentary change from a mud-dominated open platform to a carbonate platform with well-defined depositional domains and facies belts (3 in Fig. 13). Lateral facies correlation for this stage shows that the shallower platform environments were located to the east, in the Llevant Mountains domain (Cutri, S'Heretat and Son Maina sections, Figs. 3, 13, 14). Here, dominating facies are inner platform lagoonal facies 6A-6B interbedded with oolitic-peloidal sands deposited in marginal to internal bars and shoals (facies $5 \mathrm{~A}-5 \mathrm{C}$; Fig. 14). The lagoonal facies are rich in bivalves, calcareous algae and benthic foraminifera, which indicate openmarine conditions but still in a shallow inner platform setting (open lagoon). Tidal-flat facies associations, composed of inter- to supratidal microbial laminite, flat-pebble breccia and fenestral mudstone, are volumetrically minor (Fig. 14) and appear as thin beds capping typical shallowing-upward meter-scale cycles (Strasser 1991; Fig. 10g). In the Cutri section (Figs. 3 and 11a), the onset of stage 3 is recognized by the development of an erosional surface that truncates the underlying limestone strata of the previous stage. It separates the muddy shallow open-platform deposits of stage 2 from overlying peritidal facies of stage 3 (Fig. 11b). The surface is coated by a ferruginous crust partially reworked in clasts forming the basal lags of shallow tidal channels associated to the intertidal deposits of the base of stage 3 (Fig. 11c). Above this surface there is a general upward evolution from a predominance of subtidal-peritidal facies in the lower part of the succession, to a predominance of stacked oolitic grainstone (facies 5A, 5C) and dolograinstone (facies 5D), followed by peloidal-skeletal grainstone (facies 11) with siliciclastic influence (quartz sand grains) at the end of this stage. These facies represent the deposits of high-energy oolitic shoals, subtidal bars and sand sheets likely located at or near the platform margin, and above or close to fair weather wave base (Figs. 4, 13). Therefore, the described evolution is interpreted as resulting from an upward retrogradation of facies belts. Backward to these shoals and sands sheets (S'Heretat and Son Maina sections), facies associations show a predominance of subtidal lower energy deposits (Fig. 14), which consist of peloidal-oncolitic-oolitic grainstone (facies $5 \mathrm{C}$ ) and foraminiferal to skeletal wackestone with bivalves (facies 6A-6B), deposited in back-shoal and lagoonal environments in the platform interior. In the 


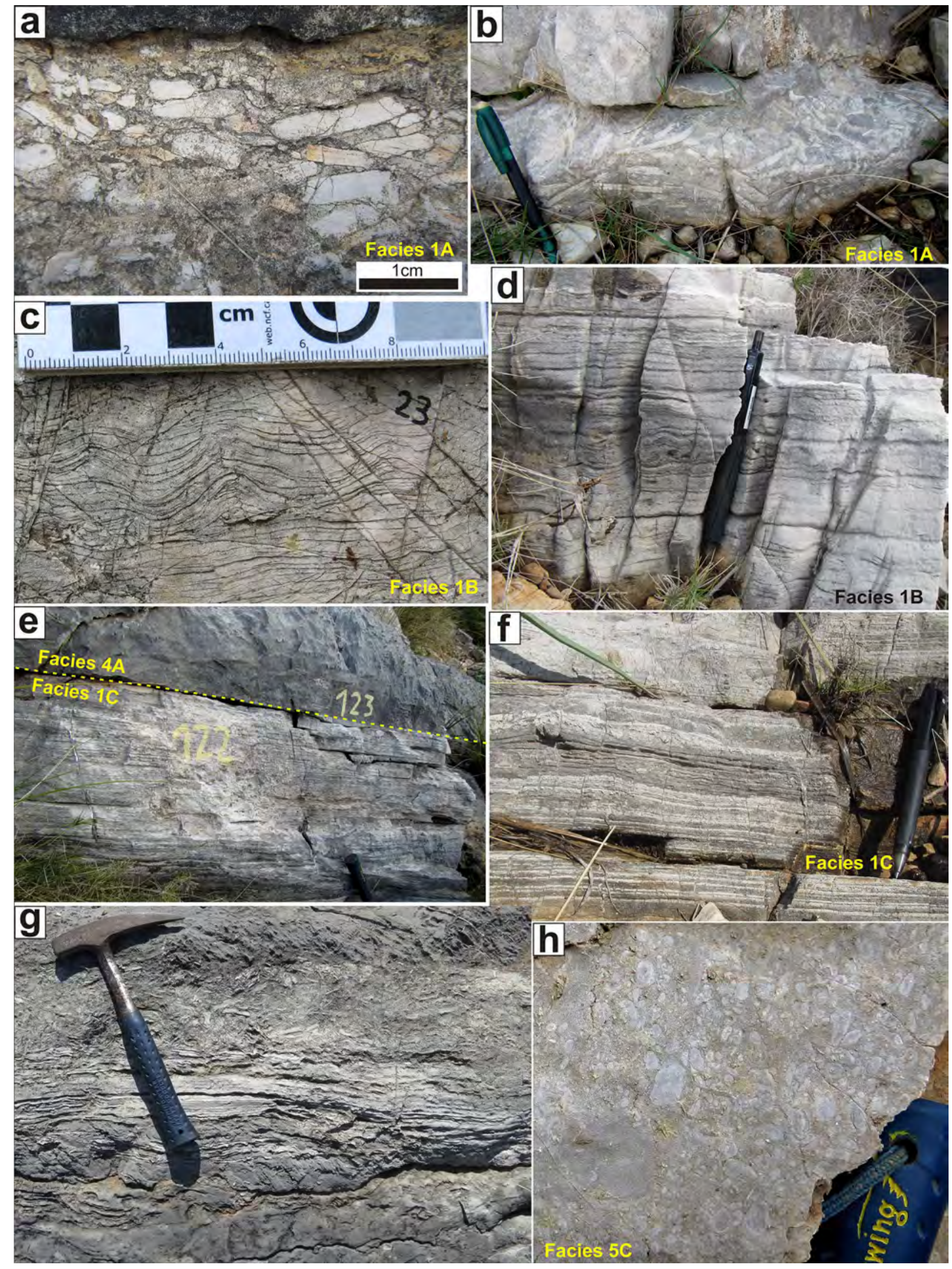


४Fig. 10 a, b Examples of supratidal flat-pebble breccia (facies 1A) in the Cutri section. Centimeter size flat pebbles are made of microbial laminites. c, d Field aspect of wavy microbial laminites (facies 1B), examples from the Es Barraca section (c) and the Cutri section (d). e Vertical stacking of intertidal facies 1C overlain by protected lagoonal facies 4A. Field example from the Cutri section. f Parallel microbial laminites (facies 1C) from Cuevas de Artá section. Note light grey color for the micritic laminae and dark grey color for the grain-supported laminae. g Field aspect of intertidal microbial laminites grading upward to supratidal flat-pebble breccias. Field example from the Cutri section. h Field aspect of peloidal-oncolitic-oolitic grainstone (facies 5C) from the Son Maina section

northeasternmost area (Cuevas de Artá section) this part of the succession is also missing (Figs. 3, 13), most likely due to erosion during subsequent extensional tectonic phases, or alternatively due to non-deposition.

Facies of middle to outer platform environments were located to the northwest, in the Tramuntana Range domain (Es Barraca and Es Cosconar sections; Figs. 13 and 14). In this domain, the change from stage 2 to stage 3 is marked by a sharp shift to marly deposits that overlie a bioturbated firmground surface (Fig. 3). In the Es Barraca section, above this surface, stage 3 starts with meter-thick intervals of marly limestone (facies 15) that alternate with massive to laminated fine-grained peloidal-skeletal packstone-grainstone rich in quartz grains (facies 11, 12B), representing likely a transition from outer to middle platform environments with storm influence (Figs. 3, 13). For the rest of the succession, fine-grained peloidal-skeletal packstones-grainstone (facies 11), fine-laminated calcisiltite with cross-bedding and climbing to hummocky cross-lamination (facies 12A), and minor amounts of peloidal-oolitic grainstone (facies 12B-12C), represent the dominant sedimentation of the middle to outer platform (Fig. 14). The sedimentary structures of these facies are interpreted as storm-driven bedforms and tempestites (Table 1; Fig. 13) (e.g., Chaudhuri 2003; Brandano et al. 2012). They intercalate with beds ( $0.5-3 \mathrm{~m}$ thick) of grain-supported intraclastic-pebbly grainstone (facies 13 ) and mud-supported oolitic-peloidal wackestone to packstone (facies 14) interpreted as probable gravity-flow deposits transporting partly lithified material in the form of intraclasts and other types of grain, from the shallower platform to the outer platform (Schlager et al. 1994). These deposits may have traveled downdip toward the outer platform triggered by tectonic instability (seismicity) or driven by strong storms that may have swept the platform. These deposits were not transported long distances downdip because they did not reach the outermost platform environment (Cosconar section), indicating the existence of gentle slopes with relative low topographic gradient that retained the sediment in this part of the platform. Upward in the succession facies evolve to predominant laminated mudstone and graded calcisiltite with ripple- to hummocky cross-lamination and cross-bedding (facies 12A-C), interpreted as storminduced bedforms and suspension mud clouds (Dott and Bourgeois 1982; Pedersen 1985).

In the Cosconar section (Fig. 3), the contact of stage 3 deposits (facies 15) with the underlying limestone of stage 2 is marked by a change to a rhythmic alternation of decimetric layers of wackestone to marly limestone and marl (facies 15; Figs. 3, 14), interpreted to have been deposited on the outermost part of the platform developed to the northwest.

\section{Discussion}

\section{Platform stages and transgressive-regressive facies cycles}

As a whole, the Liassic (Hettangian-Toarcian) carbonate succession of Mallorca shows an overall long-term deepening-upward trend from coastal sabkha and peritidal platform environments in the Hettangian-Sinemurian, to openplatform and outer-platform deposits in the Pliensbachian, and finally to hemipelagic marl-limestone alternations in the Toarcian (Álvaro et al. 1989; Rosales et al. 2018). This deepening-upward trend was coeval with a major global transgressive event (Liassic or Ligurian cycle) that affected many European and Tethyan basins (Jacquin and De Graciansky 1998; Hallam 1981, 2001).

Subordinate to this long-term transgressive event, the described Sinemurian carbonate platform stages 1-3 can be regarded as sequences, each one defined by a transgressive and/or regressive facies trend, and bounded by maximum regressive or transgressive surfaces (sensu Embry 1993) (Fig. 3). The first sequence corresponds to stage 1. It has a deepening-shallowing upward facies trend recognizable in all the studied profiles, except in the Es Barraca section, where only the upper (shallowing) part is recorded (Fig. 3). Stage 1 is characterized in its lower part by a long deepening-upward facies trend starting from the Hettangian and reflected by a gradual upward increase of the proportion of subtidal facies, with the maximum flooding interval represented by the maximum accumulation of subtidal open lagoon facies 6 (Fig. 3). The uppermost part of stage 1 shows a shallowing-upward facies trend characterized by the predominance of intertidal to supratidal carbonate deposits.

The base of stage 2 represents a sharp transgressive event in all the studied sections. This transgression is marked by a sudden facies shift from tidal-flat deposits of the uppermost part of stage 1 to outer- and open-platform deposits (facies $7 \mathrm{~B}, 8,10$ ) of the lowermost part of stage 2 . As a whole, stage 2 can be regarded as a sequence displaying a discrete shallowing-upward facies trend or even stillstand along all the studied profiles (Fig. 3). The next sequence (stage 3 ) is

\begin{tabular}{|l|l|l|l|l|}
\hline Journal : Large 10347 & Article No : 545 & Pages : $\mathbf{3 4}$ & MS Code : FACI-D-18-00047 & Dispatch : 13-12-2018 \\
\hline
\end{tabular}




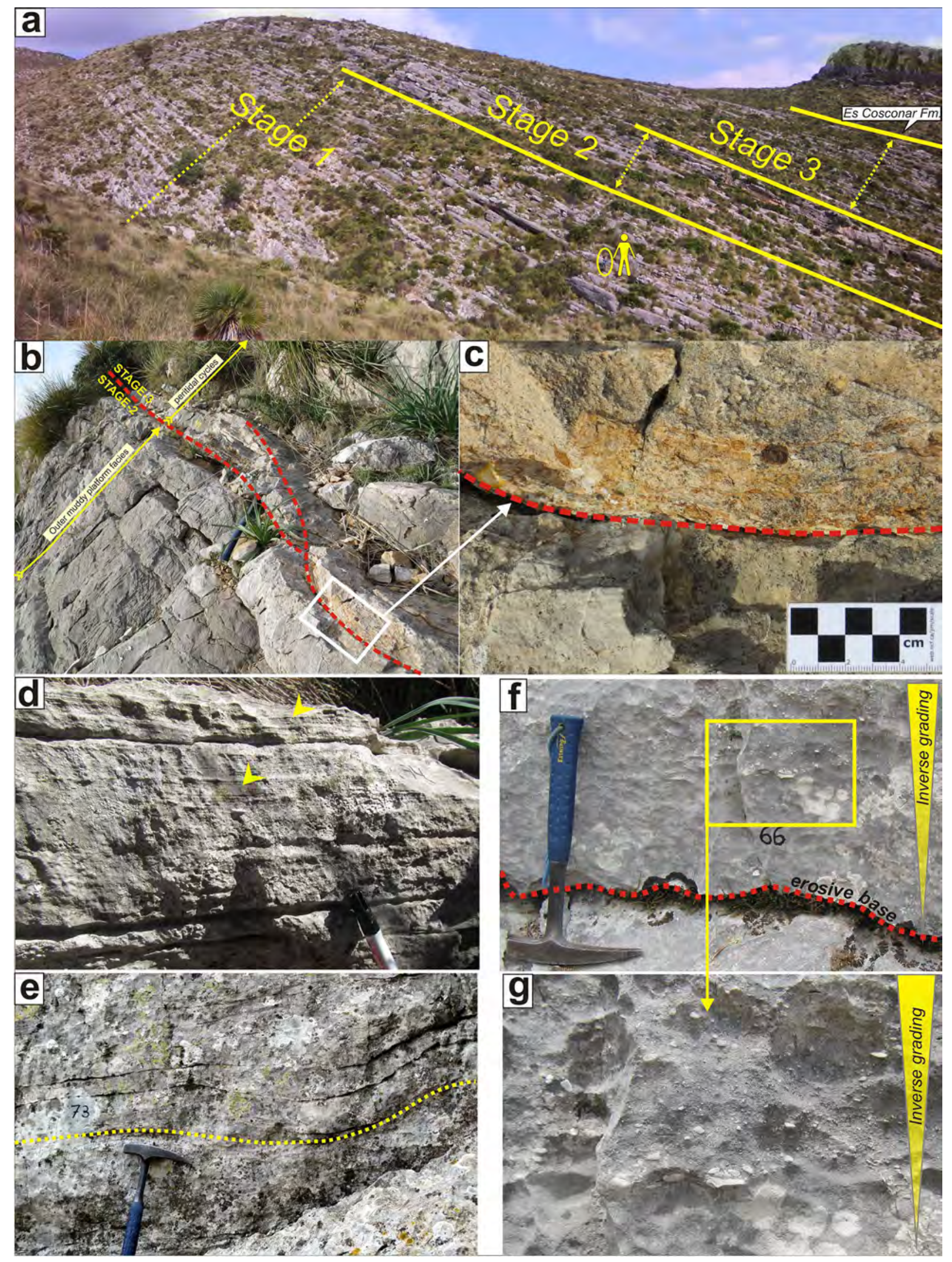


4 Fig. 11 a Field aspect of the Es Barraca Member outcrop at the Cutri section. Yellow lines indicate the upper boundary of the three different carbonate platform stages, including the top of the section in the contact with the upper Pliensbachian Es Cosconar Formation. b Contact between stage 2 and stage 3 in the Cutri section, represented by an erosional and ferruginous surface separating muddy open-platform facies of stage 2 from intertidal facies of stage 3 , with development of a probable shallow tidal channel (red lines). c Detail of the erosional surface between stage 2 and stage 3 carbonates. See clasts of the ferruginous crust deposited as a basal lag at the bottom of the tidal channel. d Field aspect of plane-parallel lamination of facies $12 \mathrm{~A}$ at the Es Barraca section. e Field aspect of undulating lamination (in-phase climbing ripples) in facies $12 \mathrm{~A}$ of the Es Barraca section. $\mathbf{f}-\mathbf{g}$ Field aspect of inverse grading observed in facies 13 (Es Barraca section)

marked by a sudden shift in the depositional system from a muddy carbonate platform to a peritidal-to-outer carbonate platform. In the inner platform environments, the sequence shows a progressive deepening-upward facies trend from tidal flat-inner platform deposits at the base of the sequence to open-platform deposits at the top (Fig. 3). This deepening-upward succession culminates with the unconformity at the boundary between the studied Es Barraca Mb and the overlying, more heterogeneous, Pliensbachian succession of marl, deltaic sandstone and platform carbonate (Sa Moleta Mb, Es Racó Mb and Es Cosconar Fm respectively; Fig. 3).

Comparison of these transgressive and regressive facies trends with the record of Jurassic sea-level changes (Hallam 2001) and the transgressive-regressive facies cycles defined for the European and Tethyan basins (De Graciansky et al. 1998; Aurell et al. 2003) shows a relatively good correlation for some of the facies trends observed. A feature common between the Mallorca record and many other more distant basins is the long transgressive trend from the Hettangian to the early Sinemurian (Hallam 1981) that is followed by a short regressive trend peaking around the early-late Sinemurian boundary (transgressive-regressive T/R 4 a sequence of De Graciansky et al. 1998). Coeval T-R sequences have also been recognized in Spain (Asturias and Basque-Cantabrian basins and the Betic Cordillera), although not in the Iberian Basin (Aurell et al. 2003). In particular, in the BasqueCantabrian basin (northern Spain), the sequence boundary capping an age-equivalent asymmetric transgressive-regressive facies cycle is evidenced by a middle Sinemurian erosional unconformity with subaerial exposure, developed over forced-regressive fluvial and shallow marine sandstone (Quesada et al. 2005). The reasonably good agreement of this facies cycle of Mallorca with other basins points to a probable eustatic influence in its development (Hallam 1981, 2001), although locally masked by regional tectonic subsidence (e.g., Iberian Basin; Aurell et al. 2003).

The early late Sinemurian transgressive event that characterizes the base of stage 2 is also a common feature observed in many other basins such as the Basque-Cantabrian and Asturias basins (Obtusum Zone transgressive surface; Aurell et al. 2003; Quesada et al. 2005). In those basins, like in Mallorca, this event is related also with the onset of differential subsidence (Aurell et al. 2003; Quesada et al. 2005). The late Sinemurian is characterized in other European basins by a new, more symmetrical, transgressive-regressive facies cycle that culminates with a sequence boundary aged from latest Sinemurian in the Basque-Cantabrian basin (Quesada et al. 2005), to the Sinemurian-Pliensbachian boundary or even early Pliensbachian age in other basins (De Graciansky et al. 1998). However, the coeval Mallorca record shows an opposite trend, that is, weak facies regression (or even stillstand; stage 2) followed by facies transgression (stage 3; Fig. 3). The discrepancy in the age of the sequence and in the facies trend observed in Mallorca is interpreted to reflect particular tectonic and sedimentary conditions in this domain related to the onset of the extensional tectonics in the area. Therefore, it is suggested that both tectonics and eustasy combined to create accommodation space and that both impacted on the internal architecture of the Sinemurian carbonate platform of Mallorca.

\section{Regional and paleoenvironmental influence on facies architecture}

Shallow-water and peritidal carbonates of Early Jurassic (Liassic) age are a common feature of many regions of the peri-Tethyan margins. They developed through the Hettangian to Pliensbachian in tropical-subtropical regions and over large epicontinental areas of the Iberian, Adriatic and African plates. These conditions led to deposition of the so-called Lower Jurassic Bahamian-type facies (sensu Beales 1958), which are characterized by peritidal facies with exposure horizons, high-energy shallow-water ooliticpeloidal grainstone, and lagoonal facies with foraminifera, oncoids and the green algae Palaeodasycladus (Di Stefano et al. 2002; Rychliński et al. 2018a, b). These Lower Jurassic Bahamian-type facies (Beales 1958) are comparable to the facies documented in this study for the stage 1 and stage 3 of the Es Barraca Mb. Similar facies have also been described in many carbonate platforms of Liassic age (Hettangian to Pliensbachian) around the Tethys, such as in Greece (Pomoni-Papaioannou and Kostopoulou 2008), Croatia (Martinuš et al. 2012), Italy (Barattolo and Bigozzi 1996; Di Stefano et al. 2002; Romano et al. 2005), Tunisia (Soussi and Ismail 2000; Soussi et al. 2000), Morocco (Crevello 1991; Wilmsen and Neuweiler 2008; MerinoTomé et al. 2012); and around the Iberian margins, in the Basque-Cantabrian Basin (Robles and Quesada 1995), the Iberian Basin (Bádenas et al. 2010) and the Betic Cordillera (Bosence et al. 2000; Ruiz-Ortiz et al. 2004), reflecting parallelism in their sedimentary conditions.

On the other hand, many of these peri-Tethyan carbonate platforms experienced extensional tectonics (rifting) since
1016 1017 1018 1019 1020 1021 1022 1023 1024 1025 1026 1027 1028 1029 1030 1031 1032 1033 1034 1035

\begin{tabular}{|l|l|l|l|l|}
\hline Journal : Large 10347 & Article No : 545 & Pages : $\mathbf{3 4}$ & MS Code : FACI-D-18-00047 & Dispatch : 13-12-2018 \\
\hline
\end{tabular}




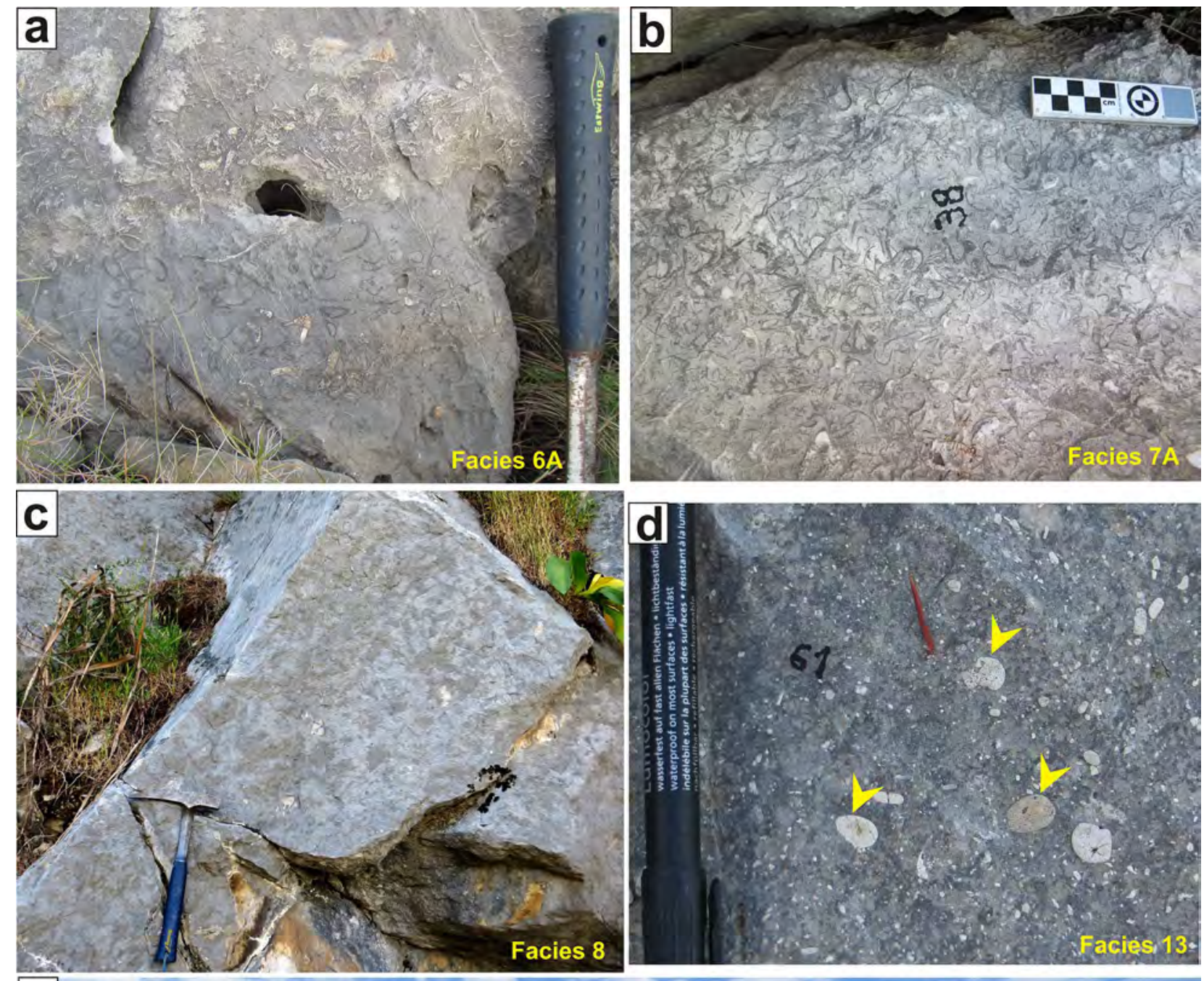

\section{Cosconar section (stage-2)}

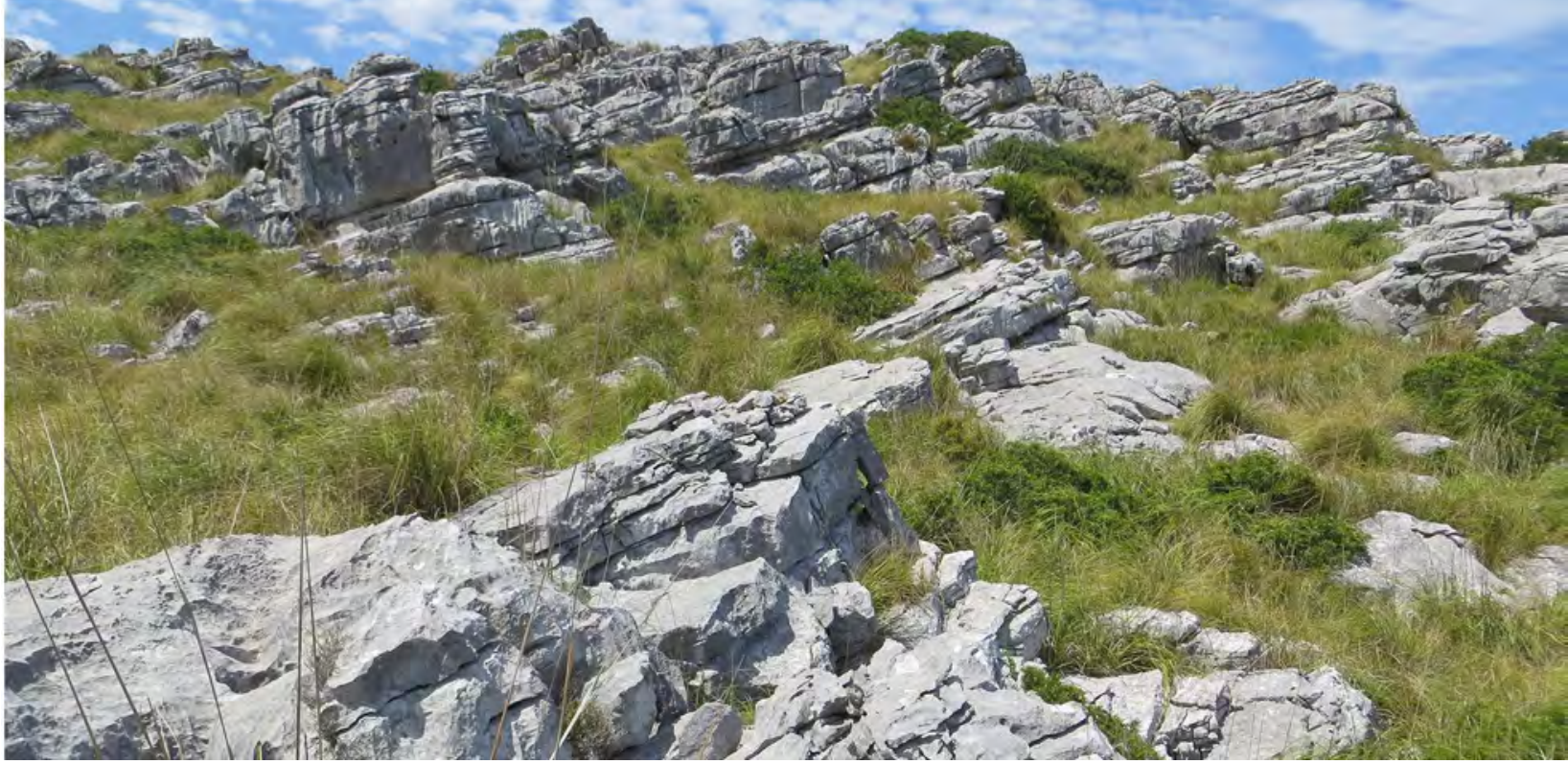


4 Fig. 12 a Field aspect of open-lagoon facies 6A. Note the abundance of bivalves and other skeletal fragments from the Cutri section. b Field aspect of skeletal floatstone (facies 7A) from the H'Heretat section. c Field aspect of bioturbated mudstone (facies 8) from the Es Barraca section. d Field aspect of heterometric-intraclastic-pebbly grainstone (facies 13) from the Es Barraca section. Yellow arrows point to limestone pebbles with different textures. e General field aspect of limestones corresponding to stage 2 in the Cosconar section

the late Sinemurian onwards, related to the opening of the central Atlantic gateway and the expansion of the western Tethys (Thierry 2000). These tectonic events resulted in a major paleogeographic reorganization of the carbonate platforms throughout the Early Jurassic, with platform dissection causing formation of up-lifted blocks and intra-shelf basins, and finally drowning, giving way to hemipelagic and pelagic deposition (e.g., Bernoulli and Jenkyns 1974; Soussi and Ismail 2000; Ruiz-Ortiz et al. 2004; Santantonio et al. 2016). The three platform stages identified for the Es Barraca Member of the Balearic Basin encompassed the early phases of this tectonic evolution. Thus, stage 1 developed during the early Sinemurian to earliest late Sinemurian as a wide shallow carbonate platform (Fig. 13), which was characterized by a very low topographic gradient and Bahamian-type facies representative of environments ranging from tidal-flat and marginal-littoral with small depressions or ponds, oolitic bars/shoals and restricted to open shallow lagoons. The platform evolved upwards, during the late Sinemurian (stage 2), to a predominantly muddy open platform rich in molluscs (bivalves, gastropods) (Fig. 13). During this stage local slumps in the Tramuntana Range domain indicate the onset of topographic gradients in this direction and/or paleosismicity, suggesting the beginning of tectonic activity in the area during the late Sinemurian. In addition, the increase of thicknesses toward the Tramuntana Range during this stage, along with the sudden occurrence of relatively deeper-water spiculitic facies (facies 10) over tidal-flat facies of the previous stage, are interpreted to represent a rapid deepening and an increase in accommodation space towards this domain. In contrast, toward the Llevant Mountains domain, the platform developed in a less-subsident area characterized by thinner sedimentary thicknesses and predominance of relatively shallower facies, composed mainly of mudstone and skeletal limestone rich in oncoids, molluscs and megalodontid bivalves (facies 7A, 7B, 8). This reflects a sharp change in the sedimentary conditions of the shallow platform, with the demise of the previous Bahamian-type facies, despite the fact that sedimentation still occurred in a shallow-marine environment. Tectonic activity is reflected also in the northeasternmost sector (Cuevas de Artá), where peritidal facies of stage 1 are directly overlain by a hardground and condensed section of Aalenian-Bajocian age (Álvaro et al. 1989). Therefore, there is a depositional gap (erosion and/or non-deposition) spanning from the early-late Sinemurian to the Aalenian, suggesting that this area was probably a structural high with negligible subsidence/accommodation space or even uplift. The shallowest environments during stage 2 were likely located towards this area but were not preserved or deposited and later removed by erosion due to uplift during rift progression. The presence of resedimented oolitic layers within the facies of the muddy shallow platform indicates the existence of a non-preserved narrow oolitic belt probably located towards this position (Fig. 13).

An almost simultaneous demise of peritidal carbonate sedimentation that was replaced by relatively deeper-water, open-marine subtidal deposition seems to have occurred around the early-late Sinemurian boundary in many other peri-Tethyan platforms. This is the case, for example, on the Apennine and Sicilian platforms (Marino and Santantonio 2010), the Ligurian Alps (Decarlis and Lualdi 2010), the Basque-Cantabrian Basin of northern Spain (Quesada et al. 2005) and the High Atlas of Morocco (Mehdi et al. 2003; Chafiki et al. 2004; Wilmsen and Neuweiler 2008). In the High Atlas of Morocco the approximate boundary between the early and late Sinemurian is characterized by the breakup of the previous peritidal carbonate platform into blocks, which is accompanied also by a demise of the carbonate factory, leading to the development of depositional hiatuses and to the replacement of the peritidal carbonate factory by micritic, microbial, siliceous sponge-rich deposits (Mehdi et al. 2003; Chafiki et al. 2004; Wilmsen and Neuweiler 2008). This suggests deepening and environmental perturbations accompanying the tectonic event. According to Masetti et al. (2017) and Preto et al. (2017), a positive excursion followed by a negative carbon isotope anomaly occurs across the transition from early to late Sinemurian in both, shallowand deep-water successions of the Southern Alps, which can be correlated to global perturbations of the carbon cycle accompanying the flooding of formerly peritidal carbonate deposition (Fig. 15). They concluded that mesotrophic conditions might have occurred during the late Sinemurian, acting together with the onset of extensional tectonics, and causing a crisis in carbonate production. The late Sinemurian negative carbon isotope excursion is reproduced also in several sections of England (Fig. 15) along with palynological evidence of warming, giving further support that may represent a climatic event (Jenkyns and Weedon 2013; Riding et al. 2013).

The evolution of the Balearic platform in the late Sinemurian may have been similar to the above-cited examples (Fig. 15), that is, the onset of tectonic differential subsidence, sea-level changes and environmental perturbations may have merged controlling the change in the platform style recorded from stage 1 to stage 2 (Figs. 4 and 13). These characteristics include the lack of intertidal and supratidal facies associations, and a higher water turbidity in the

\begin{tabular}{|l|l|l|l|l|}
\hline Journal : Large 10347 & Article No : 545 & Pages : $\mathbf{3 4}$ & MS Code : FACI-D-18-00047 & Dispatch : 13-12-2018 \\
\hline
\end{tabular}




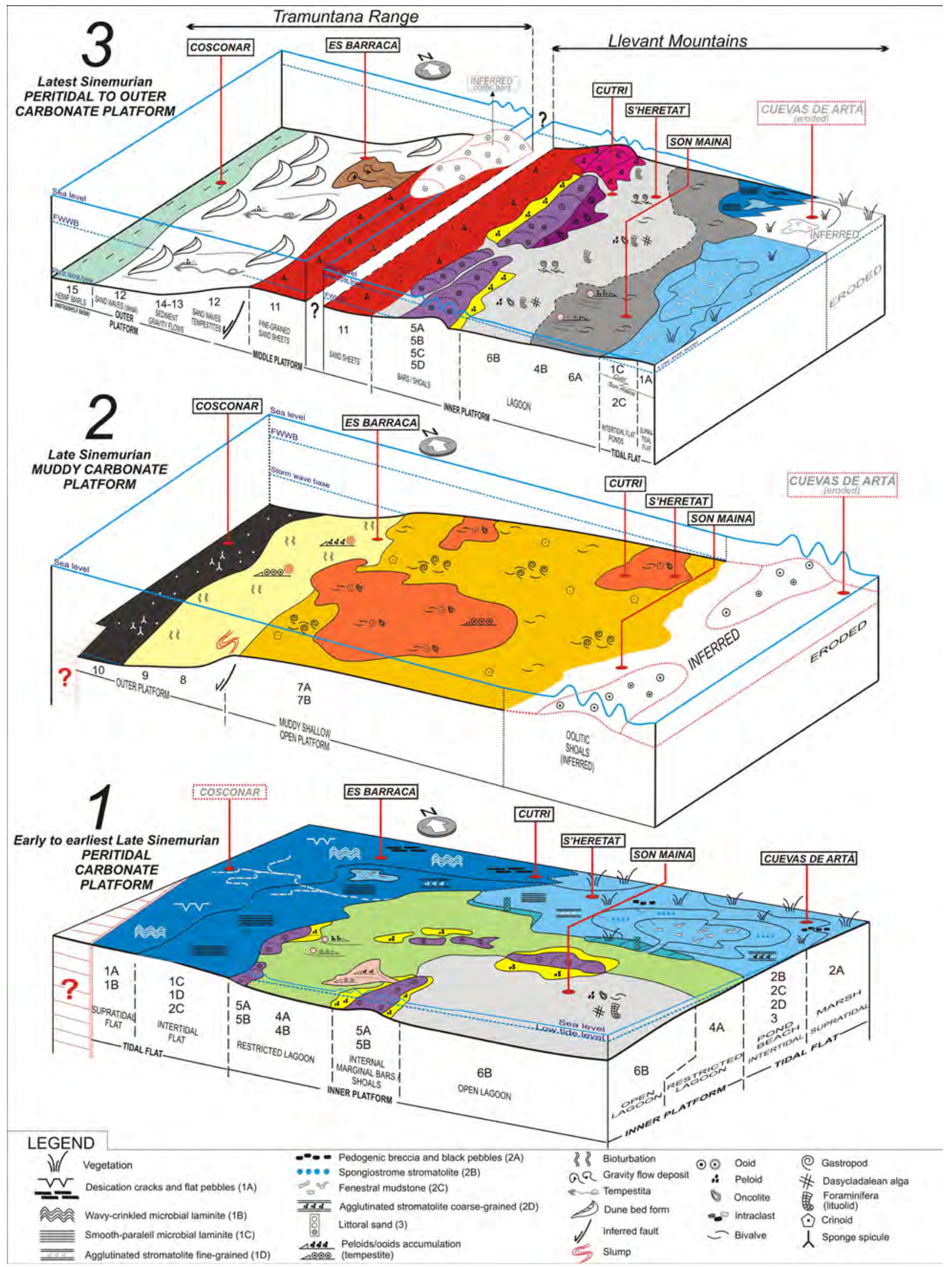


4Fig. 13 Sedimentary facies models for the three platform stages established in the evolution of the Sinemurian carbonate succession of Mallorca. These conceptual depositional models are reconstructed for the end of each stage. Stage 1: peritidal carbonate platform, early Sinemurian-earliest late Sinemurian. Stage 2: muddy open carbonate platform, late Sinemurian. Stage 3: peritidal to outer carbonate platform, latest Sinemurian subtidal environments promoted by the muddy substrates. All this could favor the proliferation and abundance of suspensivorous heterotrophic species (i.e., bivalves and other mollusc, brachiopods, sponges). The proliferation of muddy substrates in the shallow platforms of the late Sinemurian seems to have been a frequent feature reproduced in some other basins around the Iberian plate (Aurell et al. 2002; Paredes et al. 2013). This period may correspond to the
1165 1166 1167 1168 1169 1170 1171 1172
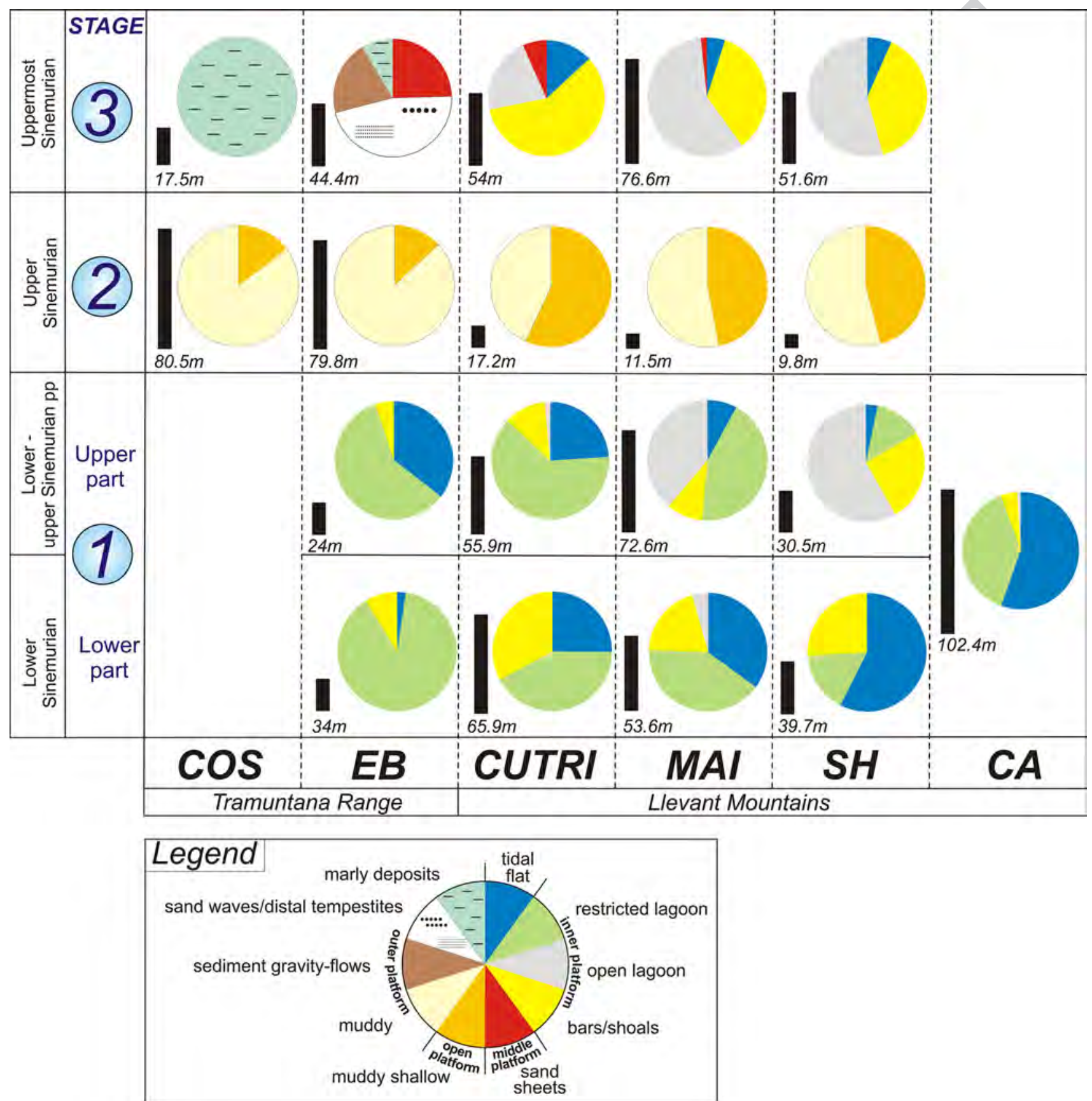

Fig. 14 Color pie charts of depositional environments, indicating the relative abundance of facies representative of the different environments for each stage of carbonate platform evolution in the six stud- ied sections. The plots of stage 1 have been separated in a lower and an upper part. These pie charts illustrate the vertical and lateral variation of facies and depositional environments through the Sinemurian

\begin{tabular}{|l|l|l|l|l|}
\hline Journal : Large 10347 & Article No : 545 & Pages : 34 & MS Code : FACI-D-18-00047 & Dispatch : 13-12-2018 \\
\hline
\end{tabular}




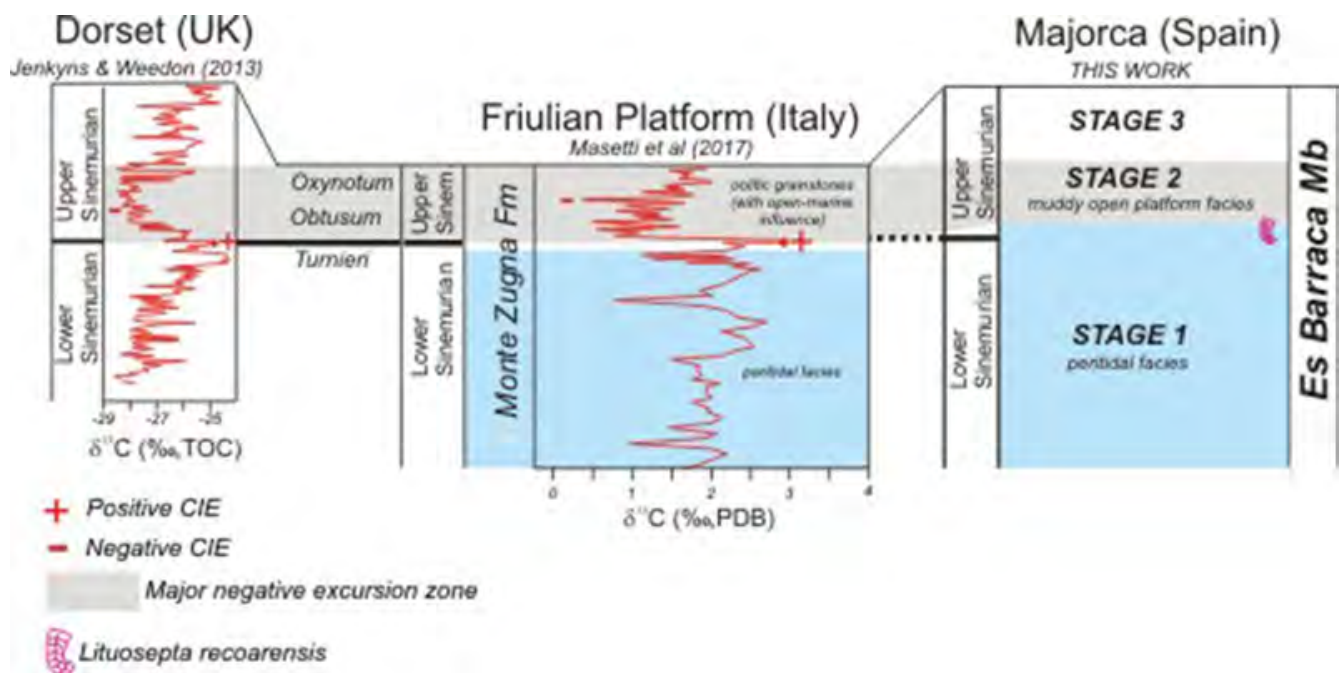

Fig. 15 A tentative correlation of the Sinemurian sedimentary and carbon isotope records from two well-documented sections in UK (Jenkyns and Weedon 2013) and Italy (Masetti et al. 2017) with the age-equivalent sedimentary record of Mallorca from this study, showing the potential link between geochemistry and temporal facies evolution. A major negative carbon isotope excursion zone (colored in

so-called "Lotharingian crisis" observed in other basins of the Western Tethys (Gabilly et al. 1985), which also coincides with a regional transgressive event (Aurell et al. 2002, 2003).

After the late Sinemurian tectonic phase with its associated change in carbonate sedimentation and deepening event, shallow-water sedimentation did not recover in many areas of the Western Tethys (Masetti et al. 2017), whereas other areas experienced a resumption of the shallow-water carbonate factory (Preto et al. 2017). The latter was also the case for the Balearic Basin, where a new carbonate platform (stage 3 ) was established during the latest Sinemurian, with recovery of the Bahamian-type carbonate deposition (Fig. 13). During stage 3 the platform evolved to a carbonate platform with well-defined facies belts, showing a transition from peritidal and innerplatform/lagoon facies in the Llevant Mountains domain to mid-outer platform environments in the Tramuntana Range domain (Fig. 13). The suggested platform profile during stage 3 is inferred from facies interpretation and comparison with other time-equivalent platforms from the peri-Tethyan domain (e.g., Merino-Tomé et al. 2012). The presence of resedimented ooids and peloids in the middle-outer platform environments (facies 13, 14) suggests that during this time the platform was probably rimmed by subtidal oolitic belts (Fig. 13). This stage recorded a notable terrigenous influence evidenced by the presence of quartz silt and sand grains and rare quartzite pebbles, especially in the facies from the middle to outer platform environments (facies 11, 13, 15). Siliciclastic influx is grey) is observed in the Obtusum-Oxynotum zones. It is related with the demise of the peritidal platform in the Friulian Platform, which could be correlated with the parallel demise of the peritidal platform of Mallorca recorded during stage 2. The symbol of Litousepta recoarensis marks the first occurrence of this taxon, which is considered an index fossil of the late Sinemurian (Septfontaine 1984; Velić 2007)

not observed in the previous stages. According to recent paleogeographic reconstructions, it is most likely that the source of these siliciclastics was the adjacent Ebro High (Fig. 1a), which was an emergent area probably reactivated during the latest Sinemurian-Pliensbachian tectonic phase (Aurell et al. 2002). Alternatively, the siliciclastics could have been sourced from other proximal basement areas that could have emerged as a result of block faulting during this time. Following this earliest tectonic pulse in the Balearic platform, rifting progressed during the early Pliensbachian and resulted in platform dissection with the development, in the Tramuntana Range, of an intrashelf basin filled with marl (Sa Moleta $\mathrm{Mb}$ ) and deltaic siliciclastics (Es Racó Mb; Fig. 3), whereas the Llevant mountains domain was probably subjected to uplift (erosion or non-deposition during the early Pliensbachian, as indicated by a stratigraphic gap with a lack of deposits of this age). In the Betic Cordillera, the first dissection by extensional faults of the shallow carbonate platform occurred also during the early Pliensbachian (Ruiz-Ortiz et al. 2004).

\section{Conclusions}

- Detailed facies analysis of six stratigraphic profiles in the Sinemurian succession of the Mallorca (Balearic Basin) has allowed the recognition of 29 facies and sub-facies, grouped into seven facies associations representative of tidal-flat, restricted lagoon, bar/shoals, inner-platform/

\begin{tabular}{|l|l|l|l|l|}
\hline Journal : Large 10347 & Article No : 545 & Pages : 34 & MS Code : FACI-D-18-00047 & Dispatch : 13-12-2018 \\
\hline
\end{tabular}


open-lagoon, muddy shallow open-platform, muddy outer- platform, and middle to outer-platform environments.

- These facies associations evolved with time reflecting three different stages of the carbonate platform evolution. The platform evolved from a broad epicontinental, low-relief peritidal carbonate platform with an assorted mosaic of tidal-flat facies, relatively restricted and openlagoon environments (stage 1, early Sinemurian to earliest late Sinemurian), to an open muddy carbonate platform that recorded the onset of tectonically induced differential subsidence (stage 2, late Sinemurian), and finally to a shallow carbonate platform, with a transition of peritidal and inner-platform environments in the Llevant Mountains paleogeographic domain to mid-outer platform environments in the Tramuntana Range domain (stage 3, latest Sinemurian).

- The changes in facies architecture, type of carbonate factory and evolution of the platform profiles between the three stages resulted from the interplay between regional tectonics, environmental perturbations and relative sea-level fluctuations. Accompanying platform flooding and onset of differential subsidence, environmental/climatic perturbations and a carbonate platform crisis occurring during the late Sinemurian may have promoted the demise of the Bahamian-type carbonate deposition of stage 1 , which was replaced by muddy substrates during stage 2 where a heterotrophic fauna (e.g., molluscs) proliferated. During stage 3, after the late Sinemurian carbonate crisis, Bahamian-type carbonate production was re-established up to the latest Sinemurian.

- The observed changes in the type of carbonate production, platform styles, facies stacking patterns and tectonic evolution compare relatively well with those of other contemporaneous platforms around the continental Tethyan margins, improving the current understanding of the evolution of Tethyan carbonate platforms during the onset of the Early Jurassic rifting phase.

Acknowledgements The authors are grateful to F. Schlagintweit and M. Septfontaine for helping and review of the benthic foraminifera and algae determinations. BB thanks the research project CGL201785,038-P subsidized by Ministerio de Economía, Industria y Competitividad of the Spanish Government, and the project E18 (Aragosaurus: Recursos Geológicos y Paleoambientes) of the Government of Aragón. We also thank the reviewers Toni Simó and Mohamed Soussi, and Associated Editor Maurice Tucker, for fruitful reviews and comments that helped to improve the original manuscript.

\section{References}

Aitken JD (1967) Classification and environmental significance of cryptalgal limestones and dolomites, with illustrations from the Cambrian and Ordovician of southwestern Alberta. J Sediment Petrol 37:1163-1178

Álvaro M, Barnolas A, Cabra P, Comas-Rengifo MJ, Fernández-López SR, Goy A, Del Olmo P, Ramírez del Pozo J, Simo A, Ureta S (1989) El Jurásico de Mallorca (Islas Baleares). Cuad Geol Ibérica 13:67-120

Aurell M, Meléndez G, Oloriz F, Bádenas B, Caracuel J, García-Ramos JC, Goy A, Linares A, Quesada S, Robles S, Rodriguez-Tovar FJ, Rosales I, Sandoval J, Suáez de Centi C, Tavera JM, Valenzuela M (2002) Jurassic. In: Gibbons W, Moreno T (eds) The geology of Spain. Geol Soc, London, pp 213-254

Aurell M, Robles S, Bádenas B, Rosales I, Quesada S, Meléndez G, García-Ramos JC (2003) Transgressive-regressive cycles and Jurassic palaeogeography of northeast Iberia. Sediment Geol 162:239-271

Azañón JM, Galindo-Zaldivar J, García-Dueñas V, Jabaloy A (2002) Alpine Tectonics II: Betic Cordillera and Balearic Islands. In: Gibbons W, Moreno T (eds) The Geology of Spain. Geol Soc, London, pp 401-416

Bádenas B, Aurell M (2010) Facies models of a shallow-water carbonate ramp based on distribution of non-skeletal grains (Kimmeridgian, Spain). Facies 56:89-110

Bádenas B, Aurell M, Bosence D (2010) Continuity and facies heterogeneities of shallow carbonate ramp cycles (Sinemurian, Lower Jurassic, north-east Spain). Sedimentology 57:1021-1048

Barattolo F, Bigozzi A (1996) Dasycladaleans and depositional environments of the Upper Triassic-Liassic carbonate platform of the Gran Sasso (central Apennines, Italy). Facies 35:163-208

Barnolas A, Simó A (1984) Sedimentología. In: Barnolas A (ed) Sedimentología del Jurásico de Mallorca: Grupo Español del Mesozoico. IGME-CGS, Madrid

Beales FW (1958) Ancient sediments of Bahamian type. AAPG Bull 42:1845-1880

Bernoulli D, Jenkyns HC (1974) Alpine, Mediterranean and central Atlantic Mesozoic facies in relation to the early evolution of the Tethys. In: Dott RH, Shaver RH (eds) Modern and ancient geosynclinal sedimentation, vol 19. SEPM Spec Publ, Broken Arrow, pp 129-160

Bosence DWJ, Wood J, Rose EPF, Qing H (2000) Low- and high frequency sea-level changes control peritidal carbonate cycles, facies and dolomitization in the Rock of Gibraltar (Early Jurassic, Iberian Peninsula). J Geol Soc London 157:61-74

Bosence DWJ, Procter E, Aurell M, Kahla AB, Boudagher-Fadel M, Casaglia F, Cirilli S, Mehdie M, Nieto L, Rey J, Scherreiks R, Soussi M, Waltham D (2009) A dominant tectonic signal in highfrequency, peritidal carbonate cycles? A regional analysis of Liassic platforms from western Tethys. J Sediment Res 79:389-415

Boudagher-Fadel MK, Bosence DWJ (2007) Early Jurassic benthic foraminiferal diversification and biozones in shallow-marine carbonates of western Tethys. Senckenb Lethaea 87:1-39

Brandano M, Lipparini L, Campagnoni V, Tomassetti L (2012) Downslope-migrating large dunes in the Chattian carbonate ramp of the Majella Mountains (central Apennines, Italy). Sediment Geol 255-256:29-41

Chafiki D, Canérot J, Souhel A, El Hairiri K, Taj Eddine K (2004) The Sinemurian carbonate mud-mounds from central High Atlas (Morocco): stratigraphy, geometry, sedimentology and geodynamic patterns. J Afr Earth Sci 39:337-346

Chaudhuri AK (2003) Climbing ripple structure and associated stormlamination from a Proterozoic carbonate platform succession:
1278

\begin{tabular}{|l|l|l|l|l|}
\hline Journal : Large 10347 & Article No : 545 & Pages : $\mathbf{3 4}$ & MS Code : FACI-D-18-00047 & Dispatch : 13-12-2018 \\
\hline
\end{tabular}


their environmental and petrogenetic significance. J Earth Syst Sci 114:199-209

Colom G (1942) Sobre nuevos hallazgos de yacimientos fosilíferos del Lias medio y superior en la Sierra Norte de Mallorca. Boletín de la Real Sociedad Española de Historia Natural. Tomo 11:221-265

Colom G (1966) Dos niveles micropaleontológicos interesantes en el Lias inferior del Sur de España y baleares. Acta Geologica Hispanica $1(3): 15-18$

Colom G (1970) Estudio litológico y micropaleontológico del Lías de la Sierra Norte y porción central de la isla de Mallorca. Memorias de la Real Academia de la Ciencias exactas, físicas y naturales de Madrid. Tomo XXIV, Mem 2

Colom G, Dufaure P (1962) Présence de la zone à Palaeodasycladus mediterraneus (Pia) dans le Lias moye du Pla de Cuber (Majorque). Comptes Rendus Acad Sci Paris 12:2617-2619

Cook HE, Mullins HT (1983) Basin margin environments. In: Scholle PA, Bebout DG, Moore CH (eds) Carbonate depositional environments, vol 33. AAPG Mem, pp 540-617

Crevello PD (1991) High-frequency carbonate cycles and stacking patterns: interplay of orbital forcing and subsidence on Lower Jurassic rift platforms, High Atlas, Morocco. In: Franseen EK, Watney WL, Kendall CGStC, Ross W (eds) Sedimentary modeling: computer simulations and methods for improved parameter definition, vol 233. Kansas Geological Survey Bulletin, pp 207-230

Dahanayake K (1977) Classification of oncoids from the Upper Jurassic carbonates of the French Jura. Sediment Geol 18:337-353

Dasgupta P, Manna P (2011) Geometrical mechanism of inverse grading in grain-flow deposits: an experimental revelation. Earth Sci Rev 104:186-198

De Graciansky PC, Jacquin T, Hesselbo SP (1998) The Ligurian cycle: an overview of the Lower Jurassic 2nd-order transgressive/regressive facies cycles in Western Europe. In: De Graciansky PC, Hardenbol J, Jacquin T, Vail PR (eds) Mesozoic and Cenozoic sequence stratigraphy of European basins, vol 60 . SEPM Spec Publ, Broken Arrow, pp 467-479

Decarlis A, Lualdi A (2010) Synrift sedimentation on the northern Tethys margin: an example from the Ligurian Alps (Upper Triassic to Lower Cretaceous, Prepiedmont domain, Italy). Int J Earth Sci 100:1589-1604

Dercourt J, Gaetani M, Vrielynck B, Barrier E, Biju-Duval B, Brunet MF, Cadet JP, Crasquin S, Sandulescu M (eds) (2000) Atlas Peri-Tethys, palaeogeographical maps, I-XX. CCGM/CGMW, Paris

Dewey JF, Pitman WC, Ryan WBF, Bonnin J (1973) Plate tectonics and the evolution of the Alpine system. Geol Soc Am Bull 84:3137-3180

Di Stefano P, Galácz A, Mallarino G, Mindszenty A, Vörös A (2002) Birth and early evolution of a Jurassic escarpment: Monte Kumeta, western Sicily. Facies 46:47-50

Dott RH, Bourgeois J (1982) Hummocky stratification: significance of its variable bedding sequences. Geol Soc Am Bull 93:663-680

Dunham RJ (1962) Classification of carbonate rocks according to depositional texture. In: Ham WE (ed) Classification of carbonate rocks. AAPG Mem 1, pp 108-121

Einsele G (1991) Submarine mass flow deposits and turbidites. In: Einsele G, Ricken W, Seilacher A (eds) Cycles and events in stratigraphy. Springer, Berlin, pp 313-339

Einsele G, Seilacher A (1991) Distinction of tempestites and turbidites. In: Einsele G, Ricken W, Seilacher A (eds) Cycles and events in stratigraphy. Springer, Berlin, pp 377-382

Embry AF (1993) Transgressive-regressive (T-R) sequence analysis of the Jurassic succession of the Sverdrup Basin, Canadian Artic Archipelago. Can J Earth Sci 30:301-320

Fallot P (1922) Étude geologique de la sierra de Majorque. Thése détat. Libr. Polytechnique Ch. Béranger, Paris i Liège
Fernández-Bastero S, Velo A, García T, Gago-Duport L, Santos A, García-Gil S, Vilas F (2000) Las glauconitas de la plataforma continental gallega: indicadores geoquímicos del grado de evolución. J Iber Geol 26:233-247

Flügel E (2010) Microfacies of carbonate rocks. Analysis, interpretation and application. Springer, Berlin

Fornós J, Rodriguea-Perea A, Sabat F (1984) El mesozoico de la Serra de Son Amoixa (Serres de Llevant, Mallorca). I Congreso Español de Geología. Tomo 1, pp 173-185

Fugagnoli A, Bassi D (2015) Taxonomic and biostratigraphic reassessment of Lituosepta recoarensis Cati, 1959 (Foraminifera, Lituolacea). J Foramin Res 45(4):402-412

Gabilly J, Carou E, Hantzpergue P (1985) Les grandes discontinuités stratigraphiques au Jurassique: témoins d'événements eustatiques, biologiques et sédimentaires. Bull Soc géol Fr 1(3):391-401

Gelabert B (1997) La estructura geológica de la mitad occidental de la isla de Mallorca. PhD Thesis. Colección MEMORIAS (IGME), pp 129

Hallam A (1981) A revised sea-level curve for the early Jurassic. J Geol Soc London 138:735-743

Hallam A (2001) A review of the broad pattern of Jurassic sea-level changes and their possible causes in the light of current knowledge. Palaeogeogr Palaeoclimatol Palaeoecol 167:23-37

Harder H (1980) Syntheses of glauconite at surface temperatures. Clays Clay Min 28:217-222

Harris PM (1986) Depositional environments of carbonate platforms. In: Warme JE, Shanley KW (eds) Carbonate depositional environments, modern and ancient, Part 2: carbonate platforms. Colorado School of Mines Quarterly 80(4):31-60

Jacquin T, De Graciansky PC (1998) Major transgressive/regressive cycles: the strati-graphic signature of European basin development. In: De Graciansky PC, Hardenbol J, Jacquin T, Vail PR (eds) Mesozoic and Cenozoic sequence Stratigraphy of European basins, vol 60. SEPM Spec Publ, Broken Arrow, pp 15-29

James NP (1984) Shallowing-upward sequences in carbonates. In: Walker RG (ed) Facies models. Geoscience Canada, pp 213-228

Jenkyns HC, Weedon GP (2013) Chemostratigaphy $\left(\mathrm{CaCO}_{3}\right.$, TOC, $\delta 13$ Corg) of Sinemurian (Lower Jurassic) black shales from the Wessex Basin, Dorset, and palaeoenvironmental implications. Newsl Stratigr 46:1-21

Leinfelder R (1987) Formation and significance of black pebbles from Ota limestone (Upper Jurassic, Portugal). Facies 17:159-170

Marino M, Santantonio M (2010) Understanding the geological record of carbonate platform drowning across rifted Tethyan margins: examples from the Lower Jurassic of the Apennines and Sicily (Italy). Sediment Geol 225:116-137

Martín-Chivelet J, Palma RM, López-Gómez J, Kietzmann DA (2011) Earthquake-induced soft-sediment deformation structures in Upper Jurassic open-marine microbialites (Neuquén Basin, Argentina). Sediment Geol 235:210-221

Martinuš M, Bucković D, Kukoč D (2012) Discontinuity surfaces recorded in shallow-marine platform carbonates: an example from the early Jurassic of the Velebit Mt. (Croatia). Facies 58:649-669

Masetti D, Figus B, Jenkyns HC, Barattolo F, Mattioli E, Posenato R (2017) Carbon-isotope anomalies and demise of carbonate platforms in the Sinemurian (early Jurassic) of the Tethyan region: evidence from the Southern Alps (northern Italy). Geol Mag 154:625-650

Mazzullo SJ (1977) Shrunken (geopetal) ooids: evidence of origin unrelated to carbonate-evaporite diagenesis. J Sediment Petrol 47:392-397

Mehdi M, Neuweiler F, Wilmsen M (2003) Les formations du Lias inférieur du Haut Atlas central de Rich (Maroc): précisions 
lithostratigraphiques et étapes de l'évolution du bassin. Bull Soc géol Fr 174:227-242

Merino-Tomé O, Della Porta G, Kenter JAM, Verwer K, Harris P, Adams EW, Playton T, Corrochano D (2012) Sequence development in an isolated carbonate platform (Lower Jurassic, Djebel Bou Dahar, High Atlas, Morocco): influence of tectonics, eustasy and carbonate production. Sedimentology 59:118-155

Miller CR, James NP, Kyser TK (2013) Genesis of blackened limestone clasts at Late Cenozoic subaerial exposure surfaces, Southern Australia. J Sediment Res 83:339-353

Paredes R, Comas-Rengifo MJ, Duarte LV (2013) Dynamics of upper Sinemurian macrobenthic groups (bivalves and brachiopods) preserved in organic-rich facies of the Lusitanian basin (western Iberia). In: Rocha R, Pais J, Kullberg JC, Finney S (eds) STRATI 2013: first international congress on stratigraphy at the cutting edge of stratigraphy. Springer, Berlin, pp 1049-1052

Payros A, Pujalte V, Tosquella J, Orue-Etxebarria X (2010) The Eocene storm-dominated foralgal ramp of the western Pyrenees (UrbasaAndia Formation): an analogue of future shallow-marine carbonate systems? Sediment Geol 228:184-204

Pedersen GK (1985) Thin, fine-grained storm layers in a muddy shelf sequence: an example from the Lower Jurassic in the Stenlille 1 well, Denmark. J Geol Soc London 142:357-374

Pomoni-Papaioannou F, Kostopoulou V (2008) Microfacies and cycle stacking pattern in Liassic peritidal carbonate strata, GavrovoTripolitza platform, Peloponnesus, Greece). Facies 54:417-431

Pratt BR, James NP, Cowan CA (1992) Peritidal carbonates. In: Walker RG, James NP (eds) Facies models: response to sea level change. Geological Association of Canada, Newfoundland, pp 303-322

Prescott DM (1988) The geochemistry and palaeoenvironmental significance of iron pisoliths and ferromanganese crusts from the Jurassic of Majorca, Spain. Eclogae Geol Helv 81:387-414

Preto N, Breda A, Dal Corso J, Franceschi M, Rocca F, Spada C, Roghi G (2017) The Loppio Oolitic Limestone (Early Jurassic, Southern Alps): a prograding oolitic body with high original porosity originated by a carbonate platform crisis and recovery. Mar Petrol Geol 79:394-411

Quesada S, Robles S, Rosales I (2005) Depositional architecture and transgressive-regressive cycles within Liassic backstepping carbonate ramps in the Basque-Cantabrian basin, northern Spain. J Geol Soc Lond 162:531-548

Ramos-Guerrero E, Rodriguez-Perea A, Sabat F, Serra-Kiel J (1989) Cenozoic tectosedimentary evolution of Mallorca Island. Geodin Acta 3(1):53-72

Riding R (1991) Classification of microbial carbonates. In: Riding R (ed) Calcareous algae and stromatolites. Springer, Heidelberg, pp $21-51$

Riding JB, Leng MJ, Kender S, Hesselbo SP, Feist-Burkhardt S (2013) Isotopic and palynological evidence for a new Early Jurassic environmental perturbation. Palaeogeogr Palaeoclimatol Palaeoecol 374:16-27

Robles S, Quesada S (1995) La rampa dominada por tempestades del Lías inferior de la zona occidental de la Cuenca Vascocantábrica. Libro de Comunicaciones, XIII Congreso Español de Sedimentología, Teruel, pp 109-110

Romano R, Barattolo F, Masetti D (2005) Biostratigraphic evidence of the middle Liassic hiatus in the Foza section (eastern sector of the Trento Platform, Calcari Grigi Formation, Venetian Prealps). Boll Soc Geol Ital 124:301-312

Rosales I, Barnolas A, Goy A, Sevillano A, Armendáriz M, LópezGarcía JM (2018) Isotope records (C-O-Sr) of late Pliensbachianearly Toarcian environmental perturbations in the westernmost Tethys (Majorca Island, Spain). Palaeogeogr Palaeoclimatol Palaeoecol 497:168-185

Ruiz-Ortiz PA, Bosence DW, Rey J, Nieto LM, Castro JM, Molina JM (2004) Tectonic control of facies architecture, sequence stratigraphy and drowning of a Liassic carbonate platform (Betic Cordillera, Southern Spain). Basin Res 16:235-257

Rychliński T, Uchman A, Gaździcki A (2018a) Lower Jurassic Bahamian-type facies in the Choč Nappe (Tatra Mts, West Carpathians, Poland) influenced by palaeocirculation in the Western Tethys. Facies 64:15

Rychliński T, Gaździcki A, Uchman A (2018b) Dasycladacean alga Palaeodasycladus in the northern Tethys (West Carpathian, Poland) and its new palaeogeographic range during the Early Jurassic. Swiss J Geosci. https://doi.org/10.1007/s00015-018-0301-z

Sabat F (1986) Estructura Geològica de les Serres de Llevant de Mallorca (Balears). PhD Thesis. Universitat de Barcelona, pp 128

Santantonio M, Fabbi S, Aldega L (2016) Mesozoic architecture of a tract of the European-Iberian continental margin: insights from preserved submarine palaeotopography in the Longobucco Basin (Calabria, southern Italy). Sediment Geol 331:94-113

Schlager W (2005) Carbonate sedimentology and sequence stratigra-AQ4 phy. SEPM Concepts in sedimentology and paleontology 8

Scotese CR, Schettino A (2017) Late Permian-Early Jurassic Paleogeography of Western Tethys and the World. In: Permo-Triassic Salt Provinces of Europe, North Africa and the Atlantic Margins Elsevier, London, pp 57-95

Septfontaine M (1984) Biozonation (a l'aide des Foraminifères imperforés) de la plate-forme interne carbonatée liasique du Haut Atlas (Maroc). Rev Micropaléont 27:209-229

Sevillano A, Rosales I, Barnolas A, Gil-Peña I, Armendáriz M, Simó JA (2010) Significado y origen microbiano de la costra ferruginosa con estromatolitos pelágicos del Jurásico de Mallorca. In: Ruiz-Omeñaca JI, Piñuea L, García-Ramos JC (eds) Comunicaciones del V Congreso del Jurásico de España. Museo del Jurásico de Asturias, pp 200-203

Sevillano A, Bádenas B, Rosales I, Barnolas A, López-García JM (2013) Facies y secuencias de la plataforma carbonatada somera sinemuriense en la isla de Mallorca (Seccion Es Barraca), España. Geogaceta 54:15-18

Shinn EA (1983) Birdseyes, fenestrae, shrinkage pores, and loferites: a reevaluation. J Sediment Res 53:619-628

Soussi M, Ismaïl MHB (2000) Platform collapse and pelagic seamount facies: Jurassic development of central Tunisia. Sediment Geol 133:93-113

Soussi M, Enay R, Mangold C, Turki MM (2000) The Jurassic events and their sedimentary and stratigraphic records on the Southern Tethyan margin in Central Tunisia. In: Crasquin-Soleau S, Barrier E (eds) Peri-Tethys, Memoir 5: new data on Peri-Tethyan sedimentary basins, vol 182. Memoires du Museum Natl d'Histoires Nat, pp 57-92

Strasser A (1986) Ooids in Purbeck limestones (Lower Cretaceous) of the Swiss and French Jura. Sedimentology 33:711-727

Strasser A (1991) Lagoonal-peritidal sequences in carbonate environments: autocyclic and allocyclic processes. In: Einsele G, Ricken W, Seilacher A (eds) Cycles and events in stratigraphy. Springer, Berlin, pp 709-721

Strasser A, Arnaud H, Baudin F, Rohl U (1995) Small-scale shallowwater carbonate sequences of resolution Guyot (Sites 866, 867, and 868). In: Winterer EL, Sager WW, Firth JV, Sinton JM (eds) Proceedings of the ocean drilling program, scientific results, vol 143, pp 119-131

Suárez-González P, Quijada EI, Benito MI, Mas R, Merinero R, Riding $R$ (2014) Origin and significance of lamination in Lower Cretaceous stromatolites and proposal for a quantitative approach. Sediment Geol 300:11-27

Thierry J (2000) Late Sinemurian (193-191 Ma). In: Dercourt J, Gaetani M, Vrielynck B, Barrier E, Biji-DubalB, Brunet MF, Cadet JP, Crasquin S, SandulescuM (eds) Atlas Peri-Tethys. Palaeogeographical Maps-explanatory notes. Commission for the Geologic Map of the World, Paris, pp 49-59 
Tucker ME, Wright VP (1990) Carbonate sedimentology. Blackwell, Oxford

Velić I (2007) Stratigraphy and palaeobiogeography of Mesozoic benthic foraminifera of the Karst Dinarides (SE Europe). Geol Croat 60:1-113

Vera JA, Jimenez de Cisneros C (1993) Palaeogeographic significance of black pebbles (Lower Cretaceous, Prebetic, southern Spain). Palaeogeogr Palaeoclimatol Palaeoecol 102:89-102

Vierek A (2010) Source and depositional processes of coarse-grained limestone event beds in Fransian slope deposits (KostomlotyMogilki quarry, Holy Cross Mountains, Poland). Geologos 16(3):153-168
Vulpuis S, Kiessling W (2018) New constraints on the last aragonitecalcite sea transition from early Jurassic ooids. Facies 64:3. https ://doi.org/10.1007/s10347-017-0516-x

Wilmsen M, Neuweiler F (2008) Biosedimentology of the Early Jurassic post-extinction carbonate depositional system, central High Atlas rift basin, Morocco. Sedimentology 55:773-807

Wright VP, Azerêdo AC (2006) How relevant is the role of macrophytic vegetation in controlling peritidal carbonate facies? Clues from Upper Jurassic of Portugal. Sediment Geol 186:147-156 


\begin{tabular}{|ll|}
\hline Journal: & $\mathbf{1 0 3 4 7}$ \\
Article: & $\mathbf{5 4 5}$ \\
\hline
\end{tabular}

\section{Author Query Form}

\section{Please ensure you fill out your response to the queries raised below and return this form along with your corrections}

Dear Author

During the process of typesetting your article, the following queries have arisen. Please check your typeset proof carefully against the queries listed below and mark the necessary changes either directly on the proof/online grid or in the 'Author's response' area provided below

\begin{tabular}{|l|l|l|}
\hline Query & Details Required & Author's Response \\
\hline AQ1 & $\begin{array}{l}\text { Please check and confirm the author [Given name: José María] [Family name: } \\
\text { López-García] are correct. Also, kindly confirm the details in the metadata are correct. }\end{array}$ & $\begin{array}{l}\text { Reference: References (Colom 1980, Schlager et al. 1994) were mentioned in the } \\
\text { manuscript; however, these were not included in the reference list. As a rule, all } \\
\text { mentioned references should be present in the reference list. Please provide the } \\
\text { reference details to be inserted in the reference list. }\end{array}$ \\
\hline AQ3 & $\begin{array}{l}\text { Figures: figure (f15) is poor in quality as it looks fuzzy. Please supply a high-resolution } \\
\text { version of the said figure preferably in .tiff or .jpeg format with 300 dpi resolution. }\end{array}$ & \\
\hline AQ4 & Please update Ref. (Schlager (2005)) with required details. & \\
\hline AQ5 & Please update Ref. (Scotese and Schettino 2017) with editors name. & \\
\hline
\end{tabular}

\begin{tabular}{|l|l|l|l|l|}
\hline Journal : Large 10347 & Article No : 545 & Pages : 1 & MS Code : FACI-D-18-00047 & Dispatch : 13-12-2018 \\
\hline
\end{tabular}

